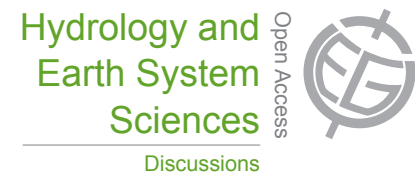

This discussion paper is/has been under review for the journal Hydrology and Earth System Sciences (HESS). Please refer to the corresponding final paper in HESS if available.

\section{Impact of bushfire and climate variability on streamflow from forested catchments in southeast Australia}

Y. Zhou ${ }^{1,2}$, Y. Zhang ${ }^{2}$, J. Vaze ${ }^{2}$, P. Lane ${ }^{3}$, and S. Xu ${ }^{1}$

${ }^{1}$ Faculty of Infrastructure Engineering, Dalian University of Technology, Dalian 116024, China ${ }^{2}$ Water for a Healthy Country Flagship, CSIRO Land and Water, G.P.O. BOX 1666, Canberra ACT 2601, Australia

${ }^{3}$ Department of Forest and Ecosystem Science, Melbourne School of Land and Environment, The University of Melbourne, 221 Bouverie St., Parkville, Victoria 3010, Australia

Received: 1 March 2013 - Accepted: 11 March 2013 - Published: 5 April 2013

Correspondence to: Y. Zhang (yongqiang.zhang@csiro.au)

Published by Copernicus Publications on behalf of the European Geosciences Union.
HESSD

10, 4397-4437, 2013

Impact of bushfire and climate

variability on

streamflow

Y. Zhou et al.

Title Page

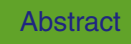

Introduction

Conclusions

References

Tables

Figures

14

$\rightarrow$

$\triangleleft$

Back

Close

Full Screen / Esc

Printer-friendly Version

Interactive Discussion 


\section{Abstract}

Most of the surface water for natural environmental and human water uses in southeast Australia is sourced from forested catchments located in the higher rainfall areas. Water yield of these catchments is mainly affected by climatic conditions, but it is also 5 greatly affected by vegetation cover change. Bushfires are a major natural disturbance in forested catchments and potentially modify the water yield of the catchments through changes to evapotranspiration (ET), interception and soil moisture storage. This paper quantifies the impacts of bushfire and climate variability on streamflow from three southeast Australian catchments where Ash Wednesday bushfires occurred in February 1983. The hydrological models used here include AWRA-L, Xinanjiang and GR4J. The three models are first calibrated against streamflow data from the pre-bushfire period and they are used to simulate runoff for the post-bushfire period with the calibrated parameters. The difference between the observed and model simulated runoff for the post-bushfire period provides an estimate of the impact of bushfire on streamflow. The tial increase in streamflow in the first $15 \mathrm{yr}$ after the 1983 bushfires. The increase in streamflow is attributed to initial decreases in ET and interception resulting from the fires, followed by logging activity. After $15 \mathrm{yr}$, streamflow dynamics are more heavily influenced by climate effects, although some impact from fire and logging regeneration may still occur. It is shown that hydrological models provide reasonable consistent estimates of forest disturbance and climate impacts on streamflow for the three catchments. The results might be used by forest managers to understand the relationship between forest disturbance and climate variability impacts on water yield in the context of climate change.

\section{HESSD}

10, 4397-4437, 2013

Impact of bushfire and climate

variability on

streamflow

Y. Zhou et al.

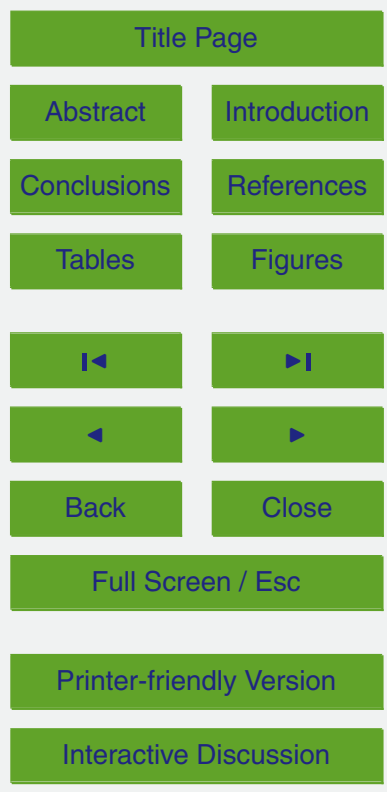




\section{Introduction}

Forested catchments are normally located in higher rainfall areas and they produce most of the surface water for natural environmental and human water use in major parts of the world. This is particularly important in southeast (SE) Australia. For instance, 5 most of the water supply for Melbourne, the capital of Victorian State, comes from native eucalypt forest catchments (Lane et al., 2010).

Water supply in SE Australian native forest catchments has been significantly influenced by natural and/or anthropogenic disturbances (Langford, 1976; Kuczera, 1987; Cornish 1993; Cornish and Vertessy, 2001; Vertessy et al., 1996, 2001; Watson et al., 1999; Lane et al., 2010). Bushfires, a major natural disturbance in SE Australia, have the potential to modify the hydrological response of forests by significantly altering interception and transpiration. To give some scale of this issue, over 3 million ha of forests in SE Australia have been subject to bushfire in the past $9 \mathrm{yr}$. The major anthropogenic forest disturbance is logging, which is a major source of pulp and timber in SE

15 Australia. Like severe fire, clearfell logging substantially changes land cover and the associated hydrological response. In some catchments, salvage logging has combined with bushfire, changing hydrological processes and thus influencing runoff generation (Smith et al., 2011).

As for most studies in which there is a dramatic change in vegetation, fire presents potential for a distinct temporal change in evapotranspiration (ET) as the early loss of leaf area transitions into regrowth or recovering forest. There are numerous examples in the literature of flow increases following forest disturbance or growth (see reviews by Bosch and Hewlett, 1982; Andréassian 2004; Brown et al., 2005; Vaze, et al., 2004). Many of the fire-related studies reported in the literature focus only on immediate and 25 short term flow increases (Brown, 1972; Helvey, 1980; Scott, 1993, 1997; Lane et al., 2006, 2012). But Tan et al. (2011) also reported no flow increases in Melbourne's water supply catchments following the 2009 Black Saturday fires in Victoria, and a recent
HESSD

10, 4397-4437, 2013

Impact of bushfire and climate

variability on

streamflow

Y. Zhou et al.

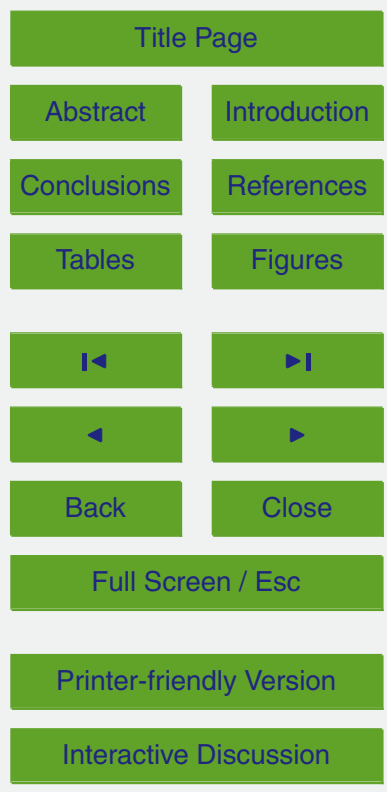


study measuring the evapotranspiration of E. delegatensis stands after fire found significant increases in stand ET in years 6-7 post fire (Buckley et al., 2012).

Two landmark studies in Australia (Langford, 1976 and Kuczera, 1987) were the first to identify a significant flow decline as the forest recovers. These studies found that 5 the regrowth stands of Eucalyptus regnans (Mountain Ash) killed in the 1939 bushfire were yielding significantly less water than the old growth stands they replaced. Kuczera (1987) proposed a model that, expressed as an age-yield curve, shows a $50 \%$ decline in flow by age $25-30$ relative to an old growth baseline, with a gradual recovery over greater than $100 \mathrm{yr}$. Watson et al. (1999a) essentially endorsed the general trend of 10 the curve, with the major departure being a flow increase in the first few years. Kuczera's analysis (Kuczera, 1987) did not identify this early increase. Both models predict streamflow to begin decreasing below pre-fire level in less than $10 \mathrm{yr}$.

The reasons for this age-yield relationship were untangled by a series of process studies (e.g. Vertessy et al., 1995, 1996, 2001; Haydon et al., 1996; Watson et al., 1999b). Fire is the ecological trigger for E. regnans and other Ash-type eucalypt forests (mainly E. delegatensis). Moderate-hot fires kill the trees which results in very dense regeneration from seed, leading to a rapid development of sapwood area and leaf area. These single aged stands thin out naturally with competition, leading to development of an understorey and gradual loss of overstorey density. As the stands thin, water use decreases.

In contrast to ash forests, the effect of fire on most other eucalypt species is far less dramatic as they are fire resistant, with relatively low incidence of mortality. Complete regrowth stands in these mixed species forests are rare. Loss of leaves in the canopy is compensated by growth of epicormic shoots from trunk and branches, and seedling germination. Gradually the canopy is re-established and the dominant trees out compete seedlings. The non-ash ET-age relationship following fire is poorly understood. However any significant long-term changes are unlikely unless there is widespread mortality. It is generally conceded that this rarely occurs (e.g. Gill, 1995; Purdie and Slatyer, 1976; Christensen et al., 1981; Vivian et al., 2008), which means the logging

Impact of bushfire and climate variability on streamflow

Y. Zhou et al.

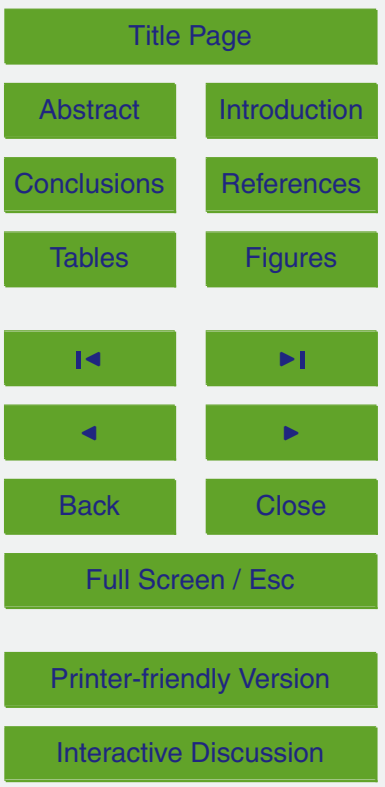


impact reported by Cornish (1993) and Cornish and Vertessy (2001) is unlikely. Although not well measured, it can be argued that these forests re-establish their canopy in less than $10 \mathrm{yr}$ (and often much faster) and return to the pre-fire equilibrium ET.

When considering bushfire impact on streamflow, climate variability is also an impor5 tant factor that can greatly affect streamflow (Dam, 1999; Lane et al., 2005). Precipitation and potential evapotranspiration are two dominant climate factors in hydrological cycle. The high variability of rainfall and temperature observed in eastern Australia (Stone and Auliciems, 1992; Kiem and Franks, 2001) significantly influence catchment hydrology. For example, a prolonged drought since the mid-1990s in southeast Aus10 tralia has had a serious impact on bushfire regimes and water availability for industrial and consumptive use (Verdon-Kidd and Kiem, 2009). There have been numerous studies investigating the impacts of land use/land cover change and climate variability on streamflow (Li et al., 2007, 2009b; Tomer and Schilling, 2009; Nangia et al., 2010; Li et al., 2012). Most of these studies focus on vegetation change due to afforestation, 15 deforestation and other human activities. However, bushfire and climate variability impacts on streamflow are rarely concerned.

To investigate forest disturbance and climate variability impacts on streamflow, hydrological modeling is extensively used. Modelling studies into forest disturbance in SE native Australian forests have included physically-based (e.g. Vertessy et al., 1993, 1995; Watson et al., 1999b), empirical (Watson et al., 1999a; Cornish and Vertessy, 2001) and lumped rainfall-runoff models (e.g. Post and Jakeman, 1996). The physically-based approaches are particularly attractive for the ash species because of the dynamic nature of stand responses. This is mainly because these models consider vegetation dynamics, simulate forest regrowth after disturbance, and then try to model runoff under transient conditions. The application of these models on catchments affected by bushfires or logging is subject to the availability of detailed catchment attributes which are necessary for the parameterisation of these models. These detailed catchment attributes at fine spatial resolution are seldom available for medium to large size catchments which normally constrains the successful application of these models. Lane
HESSD

$10,4397-4437,2013$

Impact of bushfire and climate

variability on

streamflow

Y. Zhou et al.

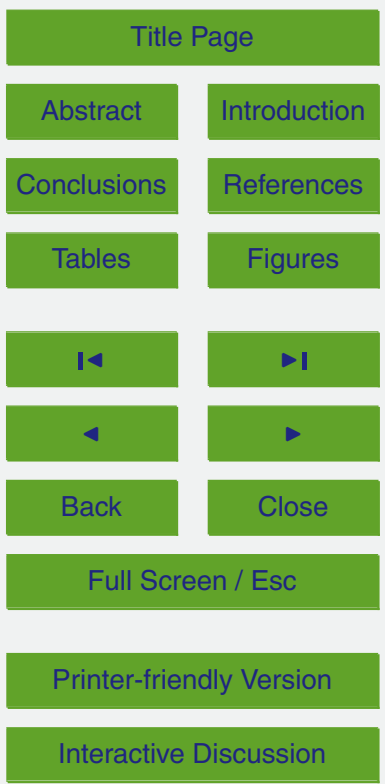


et al. (2010) highlight the strengths and weaknesses of physically-based approaches for fire modelling, and note that parameterisation for a wide range of vegetation types and climates is problematic. Bushfires disturb far greater areas and distribution of forest species than commercial logging, leading to parameterisation issues. Empirical mod5 els have been usefully applied for forecasting at large scales for recent Victorian fire events (Mannik et al., 2009). Although this approach avoids some parameterisation issues by neglecting rainfall dynamics and internal catchment processes, it is constrained by untested assumptions of vegetation response to fire and by application to highly variable forest and landuses with a paucity of response data.

10 Lumped rainfall-runoff models have simpler model structure, fewer model parameter and less input information, compared to the physical-based models. Therefore, the lumped rainfall-runoff models are easier to calibrate and apply for hydrological modeling and they provide a convenient method to estimate the relative impacts of catchment disturbances (such as bushfire and logging) and climate variability streamflow for any size catchment. The calibrated rainfall-runoff models can be used to quantify impact of climate variability on catchment water yield and then to estimate disturbance impact (Tuteja, et al., 2007; Li et al., 2012).

The main objective of this paper is to quantify the impacts of climate variability and bushfires on streamflow from three southeast Australian catchments where Ash Wednesday bushfires occurred in February 1983 (Fig. 1) using three conceptual rainfall runoff models (AWRA-L, Xinanjiang and GR4J). The three models are first calibrated against observed streamflow obtained from the pre-bushfire period, and then the calibrated models are applied to predict streamflow for the post-bushfire period. The difference between the observed and simulated streamflow for the post-bushfire
HESSD

10, 4397-4437, 2013

Impact of bushfire and climate

variability on

streamflow

Y. Zhou et al.

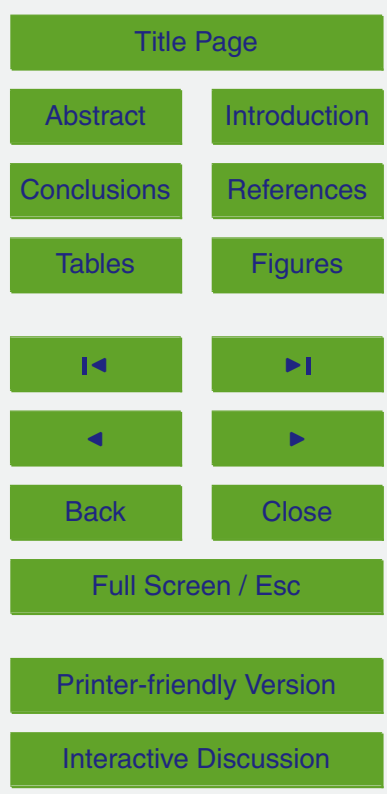




\section{Catchment and data}

\subsection{Study catchments}

The three forested catchments are situated in the Central Highlands of Victoria, east of Melbourne (Fig. 1). They are vegetated with a mix of pure E. regnans (mountain ash) 5 and mixed damp eucalypt species, predominantly $E$. obliqua, E. cypellocarpa and $E$. sieberi. The area of ash is $56 \%$ for the Latrobe River catchment, $50 \%$ for the Yarra River catchment and $51 \%$ for Starvation Creek. The ash stands were all regrowth originating from the 1939 bushfires. Table 1 provides the catchment areas, burnt area, percentage burnt and study period of record and Table 2 summarises the rainfall and areal potential evapotranspiration (APET) data.

Apportioning the vegetation impact of the burn area is not straightforward. Based on forest inventory data we can establish a minimum impact via ash mortality. This is based on the State Forest Resource Inventory (SFRI) data set that gives species and age distributions. However, the impact on the non-ash species is far less certain. We have no fire severity data for this fire. It is unlikely there was broadscale mortality, but it is impossible to know exactly what the mixed-species disturbance was. Figure 2a shows the cumulative mortality/regrowth for the catchments. It is assumed that any regeneration area from 1984 was salvage logging if fire-killed ash. The known firemortality rates for the catchments were 10\%, 25\% and 3\% for the Latrobe, Yarra 20 and Starvation Creek catchments, respectively. Figure $2 \mathrm{~b}$ includes the non-ash data, but it is unlikely that increased regeneration percentages are realistic. The area burnt for Starvation Creek is $84 \%$, but as only $3 \%$ results in a fire-kill of ash it appears the severity was not high in that catchment. Figure 2 shows clearly that, subsequent to $1983 / 84$ there was significant percentages of further disturbance. This is clearfell 25 logging (in the 1990s and early 2000s) of mountain ash and some other eucalpypt species as the post 1939 fire regrowth reached prime harvest age. Thus the analysis in this paper considers a mix of fire, logging and climate effects on streamflow.
HESSD

10, 4397-4437, 2013

Impact of bushfire and climate

variability on

streamflow

Y. Zhou et al.

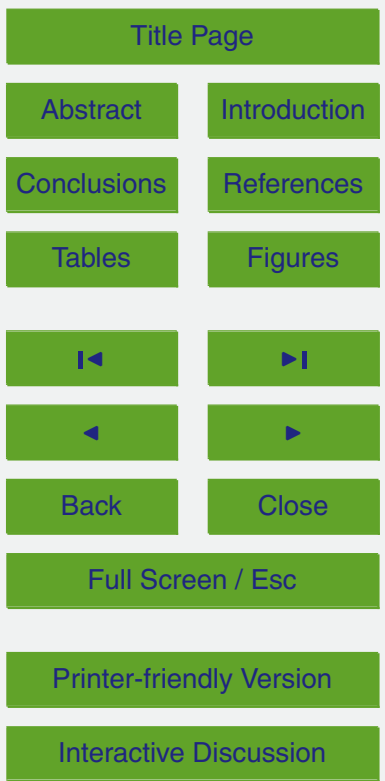




\subsection{Data}

This study uses approximately more than $30 \mathrm{yr}$ of historical streamflow data $\left(Q_{\mathrm{obs}}\right)$ extending from pre-bushfire to post-bushfire periods (Table 1). The data for the Latrobe, Yarra and Starvation Creek catchments are available for 1966-2007, 1973-2004 and

5 1971-2000, respectively. The daily streamflow data is obtained from the Victorian Water Resources Data Warehouse (http://www.vicwaterdata.net). The climatic data (daily precipitation, $P$, areal potential evapotranspiration, APET, maximum temperature, $T_{\max }$, minimum temperature, $T_{\min }$, actual vapour pressure, $e$, and solar radiation, $R_{\mathrm{s}}$ ) used in this study come from the "SILO Data Drill" produced by the Queensland Department of Environment and Resource Management (http://www.longpaddock.qld.gov.au/silo/; Jeffrey et al., 2001). The daily gridded SILO dataset $\left(0.05^{\circ} \times 0.05^{\circ}\right)$ are interpolated from 4600 point measurements across Australia (Jeffrey et al., 2001). The ordinary kriging was used to interpolate daily and monthly precipitation and cross validation indicates precipitation with a mean absolute value of $12.2 \mathrm{mmmonth}^{-1}$, indicating good quality of interpolation. The daily climatic data are used to drive the three rainfall-runoff models (AWRA-L, Xinanjiang and GR4J model). The APET used in Xinanjiang and GR4J model is calculated from the $0.05^{\circ} T_{\max }, T_{\min }, R_{\mathrm{s}}$, and $e$ using Morton's wet environment (or equilibrium evaporation or areal potential evaporation) algorithms (Morton, 1983).

\section{Methodology}

\subsection{General framework}

Streamflow is controlled not only by climate conditions, but catchment characteristics. It can be assumed that streamflow changes are resulted from climate variability and the changes in catchment characteristics, which can be written as:
HESSD

10, 4397-4437, 2013

Impact of bushfire and climate

variability on

streamflow

Y. Zhou et al.

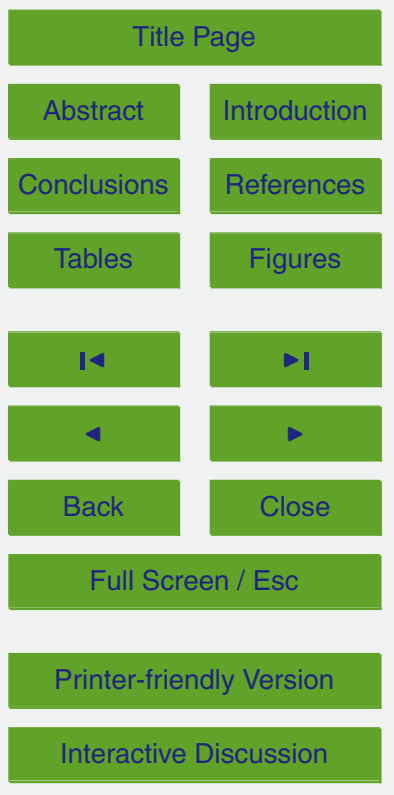


where $\Delta Q_{\text {tot }}$ is the total streamflow change in two periods, 1 and 2, estimated as $\Delta Q_{\text {tot }}=\overline{Q_{\text {obs }}^{2}}-\overline{Q_{\text {obs }}^{1}}, \overline{Q_{\text {obs }}^{1}}$ is the mean annual streamflow observed in the period 1 when catchment disturbance is negligible (the baseline) and $\overline{Q_{\text {obs }}^{2}}$ are the mean annual streamflow observed in the period 2 when catchment disturbance is significant; ${ }_{5} \Delta Q_{\mathrm{cc}}$ is the change in streamflow caused by the change in catchment characteristics, $\Delta Q_{\text {clim }}$ is the change contributed by climate variability.

The three forested catchments selected in this study are not subject to dam regulations or diversions. Therefore, changes of catchment characteristics are primarily due to vegetation changes $\left(\Delta Q_{\text {veg }}\right)$. As a result, $\Delta Q_{\mathrm{cc}}$ is replaced by $\Delta Q_{\text {veg }}$ and Eq. (1) can 10 be rewritten as:

$$
\Delta Q_{\text {tot }}=\Delta Q_{\text {veg }}+\Delta Q_{\text {clim }}
$$

$\Delta Q_{\text {tot }}$ can be estimated from streamflow data observed from the two periods. $\Delta Q_{\text {veg }}$ can be quantified once $\Delta Q_{\text {clim }}$ is available. Here, the lumped rainfall-runoff models are used to estimate $\Delta Q_{\text {clim }}$. First, these models are driven by climate inputs and calibrated against observed streamflow data in the period 1. Second, the calibrated models are driven by climate inputs in the period 2 to simulate streamflow in that period. Since these models are only driven by climate variables, rainfall and areal potential evaporatranspiration (APET), the changes in the simulated streamflow from the two periods are solely caused by climate variability. Therefore, the climatic variability impact on streamflow $\left(\Delta Q_{\text {clim }}\right)$ can be estimated as:

$\Delta Q_{\text {clim }}=Q_{\text {sim } 2}-Q_{\text {sim } 1}$

where $Q_{\text {sim } 1}$ is the mean annual streamflow simulated in the calibration period, $Q_{\text {sim2 }}$ is the mean annual streamflow simulated in the test period (or the vegetation change period).

25 This approach assumes that there are no noticeable changes in model bias from model calibration period (pre-bushfire) to model test period (post-bushfire) and the 4405

HESSD

10, 4397-4437, 2013

Impact of bushfire and climate

variability on

streamflow

Y. Zhou et al.

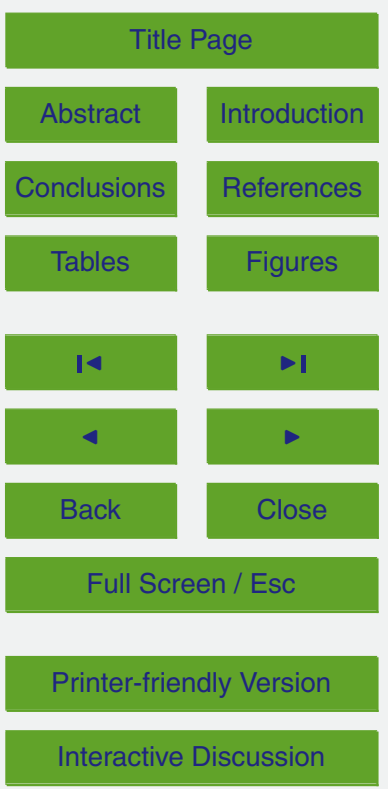


calibrated parameter set can be transferred from the calibration period to the test period. Once $\Delta Q_{\text {clim }}$ is quantified, $\Delta Q_{\text {veg }}$ is calculated from Eqs. (2) and (3).

\subsection{Hydrological modelling}

Three hydrological models, GR4J, XAJ and AWRA-L, are used in this study. Table 4 5 summarises the major characteristics and differences between the three models. All these three models have runoff generation soil stores and account for actual evapotranspiration processes. The main feature for the AWRA-L model is that it considers hydrological response units (HRUs) for each grid or catchment, and can be used for simulating vegetation processes as well. The XAJ model considers that the soil water storage is distributed in a statistical way in space across the catchment. The GR4J model adopts two unit hydrographs for routing. The three models are briefly described below.

\subsubsection{Model description}

\section{GR4J}

15 The GR4J model is a daily lumped conceptual rainfall-runoff model. Streamflow is estimated from mean areal daily $P$ and APET time series. It has two stores, the production and routing stores, and four parameters to calibrate. It has been applied over a wide range of hydro-climatic conditions (Perrin et al., 2003; Coron et al., 2012; Lerat et al., 2012) including application across southeast Australia (Vaze et al., 2010) and used in the MOPEX experiment of rainfall-runoff models intercomparison (Andréassian et al., 2006).

\section{Xinanjiang}

Xinanjiang model is also a lumped conceptual daily rainfall-runoff model. Model inputs include $P$ and APET time series. It has been widely applied in humid and semi-humid
HESSD

10, 4397-4437, 2013

Impact of bushfire and climate

variability on

streamflow

Y. Zhou et al.

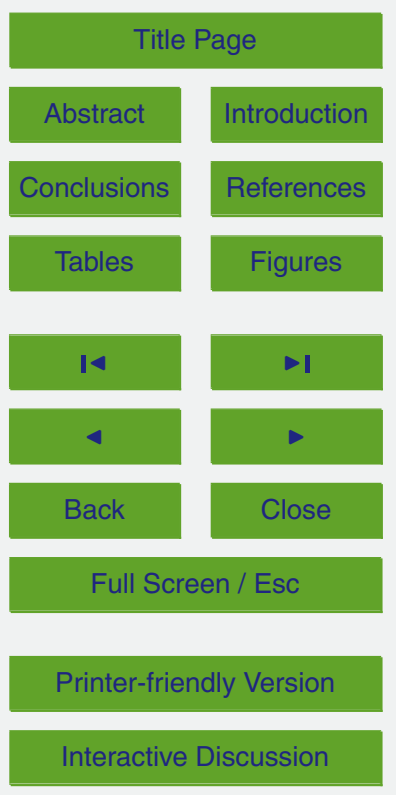


regions in China since its publication in the year of 1980 (Zhao et al., 1980; Zhao, 1992; Jayawardena and Zhou, 2000; Cheng et al., 2002). And It has been successfully applied in southeast Australia (Zhang and Chiew, 2009; Li et al., 2012). The Xinanjiang model includes 14 parameters and four submodels: a three-layer evapotranspiration 5 submodel, a runoff generation submodel, a runoff separation submodel and a runoff routing submodel.

\section{AWRA-L}

Australian Water Resources Assessment system Landscape Model (AWRA-L) (Van Dijk, 2010) is a one-dimensional, grid-based water balance model that simulates water stores and flows in the soil, groundwater and surface water systems. Each grid cell consists of two hydrological response units (HRUs): deep-rooted and shallow-rooted vegetations. Soil and vegetation water and energy fluxes are simulated separately for each HRU and individual HRUs are linked together by groundwater and surface water. The AWRAL model contains 17 calibration parameters and four submodels for simulating runoff generation, radiation and energy, vapor fluxes and vegetation phenology, respectively. The forcing data include daily precipitation, maximum temperature, minimum temperature and solar radiation and the outputs include daily water fluxes and vegetation dynamics.

\subsubsection{Calibration}

20 The particle swarm optimization (Eberhart and Kennedy, 1995) is used for model calibration. This method can find the so-called global or near-global optimum and has been successfully used for calibrating hydrological models (Chau, 2006; Gill et al., 2006; Zhang and Chiew, 2009).

All conceptual hydrological models need to be calibrated before they can be applied for catchment water balance assessments. The Nash-Sutcliffe Efficiency (NSE, defined by Nash and Sutcliffe, 1970) is the most widely used for calibration and evaluation of
HESSD

10, 4397-4437, 2013

Impact of bushfire

and climate

variability on

streamflow

Y. Zhou et al.

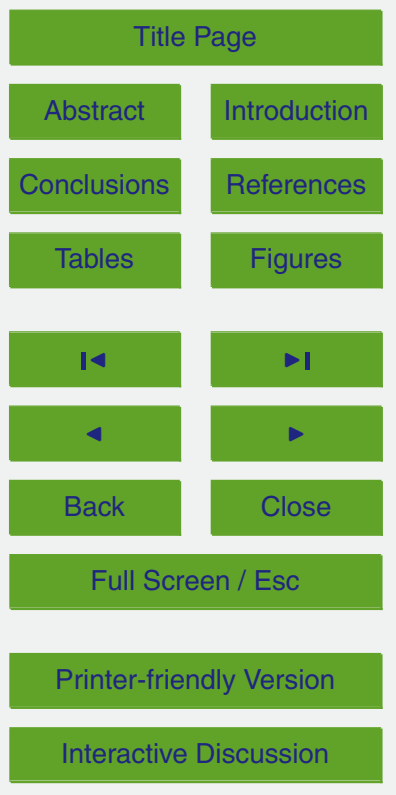


hydrological models. The hydrological models (AWRA-L, Xinanjiang and GR4J models) are calibrated by maximising the objective function which is a weighted combination of NSE of monthly runoff and a logarithmic function of bias (total model error divided by total observed streamflow, B) (Viney et al., 2009; Vaze et al., 2003) given by:

${ }_{5} \quad F=\mathrm{NSE}-5|\ln (1+B)|^{2.5}$

NSE is expressed as

$$
\mathrm{NSE}=1-\frac{\sum_{i=1}^{n}\left(Q_{\mathrm{obs}, i}-Q_{\mathrm{sim}, i}\right)^{2}}{\sum_{i=1}^{n}\left(Q_{\mathrm{obs}, i}-\overline{Q_{\mathrm{obs}}}\right)^{2}}
$$

$B$ is defined as:

$$
B=\frac{\sum_{i=1}^{n} Q_{\mathrm{sim}, i}-\sum_{i=1}^{n} Q_{\mathrm{obs}, i}}{\sum_{i=1}^{n} Q_{\mathrm{obs}, i}}
$$

10 Where $Q_{\text {obs }}$ is recorded monthly runoff, $Q_{\text {sim }}$ is simulated monthly runoff, $\overline{Q_{\text {obs }}}$ is the arithmetic mean of the observed runoff, $i$ is $i$ th month, and $n$ is the number of months. This objective function provides a smooth but less severe bias constraint, compared to the bucket constraint and an advantage of the log-bias constraint is that it does not suffer from the numerical issues which can influence predictions/simulations using the non-continuous bucket constraint (Viney et al., 2009).

The pre-bushfire period (start of flow record to 1982) is used for model calibration and the post-bushfire period (1983 to end of flow record) is used as the test period. Table 1 summarises the calibration and test periods for each catchment, with the first year of calibration period used for model warm up.

Impact of bushfire and climate

variability on

streamflow

Y. Zhou et al.

Title Page

Abstract Introduction

Conclusions

Tables

References

Figures

14

$\rightarrow 1$

$\triangleleft$

Back

Close

Full Screen / Esc

Printer-friendly Version

Interactive Discussion 


\section{Results and discussion}

\subsection{Hydrological model calibration}

The hydrological models calibration and test periods and the calibration results for the study catchments are shown in Table 1 and Table 3, respectively. The NSE results of 5 calibration period for the three models range from 0.78 to $0.85,0.78$ to 0.85 and 0.67 to 0.83 for AWRA-L, Xinanjiang and GR4J models, respectively. The calibration $B$ values range from $-0.76 \%$ to $0.39 \%$ for AWRA-L, from $0.66 \%$ to $2.65 \%$ for Xinanjiang and from $-0.57 \%$ to $2.29 \%$ for GR4J model. The predicted and observed annual streamflow for the entire modelling periods are shown in Figs. 3-5. There is a good agreement between the simulated and observed streamflow in the calibration period (start of flow record to 1982). The calibration results for the three models are satisfactory and are comparable with other hydrological model calibration results reported in literature (Vaze and Teng, 2011; Vaze et al., 2011). The calibration results also indicate that the model bias in simulating monthly runoff is small and non-systematic and the models used in this study are robust to simulate streamflow over an independent test period.

\subsection{Hydrological model simulation}

The calibrated rainfall-runoff model(s) parameters combined with climatic data $(P$, APET, $T_{\max }, T_{\min }, R_{\mathrm{s}}$, and $e$ ) are applied to simulate streamflow for the entire postbushfire test periods (Table 1) to investigate 1983 bushfire impact on streamflow from the three catchments. As the hydrological models are driven using observed climatic dataset for the post-bushfire period, it can be assumed that climatic difference impact between pre- and post-bushfire periods has been taken out. Therefore, the difference in observed and predicted streamflow during post-bushfire period is solely due to reduction in interception and actual evapotranspiration from the forest due to bushfire.

The observed and simulated streamflow for the three catchments are shown in Figs. 3-5. For all the three catchments, simulated annual streamflow from the three
HESSD

10, 4397-4437, 2013

Impact of bushfire and climate

variability on

streamflow

Y. Zhou et al.

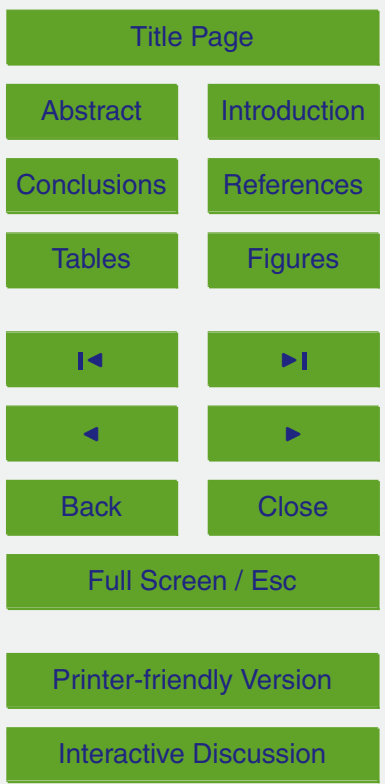


models are noticeably lower than the observed streamflow in the initial period postbushfire (1983-1998). In the period after 1999, the three models simulated runoff is in reasonable agreement with the observed runoff.

To quantify the relative impacts of 1983 bushfire and climate variability on streamflow 5 during the post-bushfire test period, the simulated streamflow for the AWRA-L, Xinanjiang and GR4J models are compared with the observed streamflow (Sect. 3.1 detailing the methodology). The difference in observed and simulated streamflow is due to vegetation cover change during the pre-bushfire and post-bushfire periods. The climate variability impact on streamflow is the difference of simulated streamflow between pre10 and post-bushfire periods. Table 5 shows the simulation results for the AWRA-L model (columns 5 to 8), Xinanjiang model (columns 9 to 12) and GR4J (columns 13 to 16) when using post-bushfire climate dataset and calibrated parameters from calibration periods.

As shown in Table 5, the total streamflow change for the first $15 \mathrm{yr}$ post-bushfire 15 show an increase (when compared to the pre-bushfire period) $\Delta Q_{\text {tot }}$ caused by the 1983 bushfires and climate variability for the Latrobe at Noojee, Starvation creek and Yarra River at Little Yarra catchments are $52 \mathrm{~mm}, 107 \mathrm{~mm}$ and $36 \mathrm{~mm}$ which represent about $17 \%, 26 \%$ and $12 \%$ increase in streamflow respectively. Table 5 summarises the relative effects of climate variability and vegetation change on streamflow from the three hydrological models. During the first $15 \mathrm{yr}$ post-bushfire, all the three models show that $\left(\Delta Q_{\text {veg }}\right)$ reduction in forest cover causes an increase in streamflow and the simulation results are similar in magnitude for the three catchments. When averaged over the three models, the increases in streamflow caused by reduction in forest cover post-bushfire are $80 \mathrm{~mm}, 136 \mathrm{~mm}$ and $30 \mathrm{~mm}(26.4 \%, 32.6 \%$ and $9.9 \%)$ for Latrob at

Noojee, Starvation Creek and Yarra River at Little Yarra catchments, respectively. Compared to the impact of bushfire, the impact of climate variability $\left(\Delta Q_{\text {clim }}\right)$ is small for all the three catchments. When averaged over the three models, the changes in streamflow caused by climate variability are $-35 \mathrm{~mm},-6 \mathrm{~mm}$ and $2 \mathrm{~mm}(-10.4 \%,-1.4 \%$ and $0.7 \%$ of pre-bushfire streamflow) for Latrob at Noojee, Starvation Creek and Yarra
HESSD

$10,4397-4437,2013$

Impact of bushfire and climate

variability on

streamflow

Y. Zhou et al.

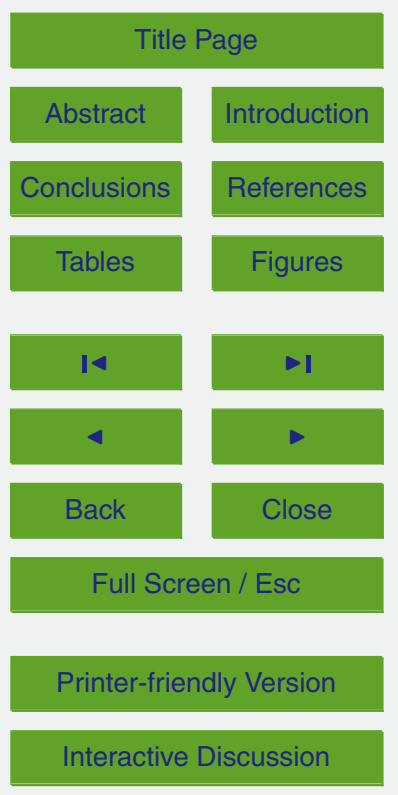


River at Little Yarra catchments, respectively. The streamflow changes caused by climate variability are similar to what we will get based on the concept of streamflow elasticity to rainfall (Chiew, 2006; see Table 2, rainfall changes of $-19 \mathrm{~mm},-17 \mathrm{~mm}$ and $20 \mathrm{~mm}(-1.3 \%,-1.0 \%$ and $1.4 \%)$ in first $15 \mathrm{yr}$ post-bushfire period compared with 5 pre-bushfire period). As shown in Figs. 6 and 7, the median of the increases in streamflow due to vegetation cover change are $79 \mathrm{~mm}, 143 \mathrm{~mm}$ and $33 \mathrm{~mm}(26 \%, 34 \%$ and $11 \%$ of pre-bushfire streamflow), and the corresponding changes in streamflow due to climatic differences between the pre-bushfire and the first $15 \mathrm{yr}$ post-bushfire periods for the three catchments are $28 \mathrm{~mm},-36 \mathrm{~mm}$ and $3 \mathrm{~mm}(-9 \%,-9 \%$ and $1 \%$ of 10 pre-bushfire streamflow). The consistency in modelling results from the three models indicates that the increase in streamflow in the first $15 \mathrm{yr}$ of post-bushfire period is mainly caused by reduction in forest cover due to bushfire.

The results for the period post 1998 (after $15 \mathrm{yr}$ post-bushfire) show that the impact of the 1983 bushfires on streamflow for the three catchments is smaller compared to that in the first $15 \mathrm{yr}$ after bushfire. For Latrobe at Noojee, Starvation creek and Yarra River at Little Yarra catchments, the total change in observed streamflow compared to the pre-bushfire period $\left(\Delta Q_{\text {tot }}\right)$ are $-87 \mathrm{~mm},-101 \mathrm{~mm}$ and $-86 \mathrm{~mm}$ which represent about $29 \%, 24 \%$ and $28 \%$ reduction in streamflow of pre-bushfire period respectively. For the post 1998 period, the reduction in streamflow due to climate variability is larger than that caused by forest cover change due to 1983 bushfire as the observed climate is significantly drier than that in the pre-bushfire period (and slightly drier than the climate for the first $15 \mathrm{yr}$ post-bushfire period) (Table 5). When averaged over the three models, the reductions in streamflow caused by climate variability for the three catchments are $-91 \mathrm{~mm},-122 \mathrm{~mm}$ and $-57 \mathrm{~mm}(-30 \%,-29 \%$ and $-19 \%$ of pre-bushfire streamflow). The three models show increases in streamflow due vegetation cover change for Latrobe at Noojee and Starvation Creek catchments. But the three models show a mixed response to vegetation cover change in Yarra River at Little Yarra catchment. AWRA-L and GR4J show reductions of $-25 \mathrm{~mm}$ and $-29 \mathrm{~mm}(-8.4 \%$ and $-9.5 \%$ of pre-bushfire period) in streamflow, while Xinanjiang model shows an increase of $8 \mathrm{~mm}$
HESSD

$10,4397-4437,2013$

Impact of bushfire and climate

variability on

streamflow

Y. Zhou et al.

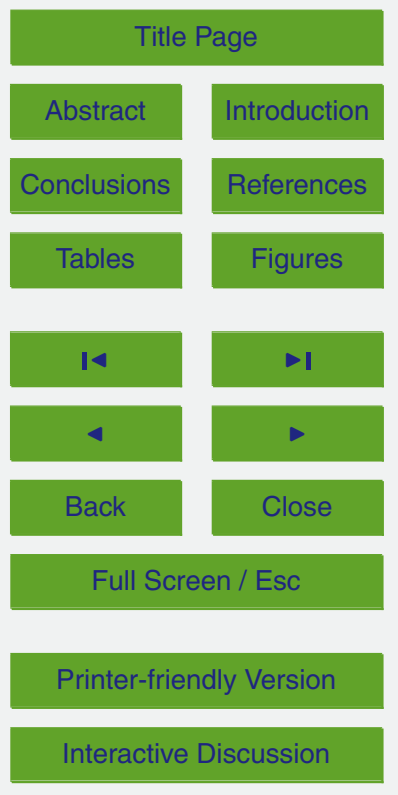


( $2.7 \%$ of pre-bushfire period) due to vegetation cover change. The Xinanjiang model is specifically developed for humid and semi-humid catchments (Zhao et al., 1980, 1992) and so the difference between Xinanjiang and AWRA-L and GR4J models is partially due to transposability of model parameters from wet to dry periods for the Xinanjiang 5 model (as discussed in Sect. 4.4). When averaged over the three models, the results in streamflow change caused by vegetation cover change compared to pre-bushfire period for the three catchments are $27 \mathrm{~mm}, 32 \mathrm{~mm}$ and $-15 \mathrm{~mm}(9.0 \%, 7.7 \%$ and $-5.1 \%$ of pre-bushfire streamflow). As shown in Figs. 6 and 7, the median of the increases in streamflow due to vegetation cover change are $30 \mathrm{~mm}, 27 \mathrm{~mm}$ and $-25 \mathrm{~mm}(10 \%$, $107 \%$ and $-8 \%$ ), and the corresponding changes in streamflow caused by climatic differences between the pre-bushfire and after $15 \mathrm{yr}$ post-bushfire periods for the three catchments are $-117 \mathrm{~mm},-129 \mathrm{~mm}$ and $-60 \mathrm{~mm}(-39 \%,-31 \%$ and $-20 \%$ of prebushfire streamflow). The consistency in the modelling results from the three models suggest that the impact of climate variability on streamflow is much larger than that caused by forest cover change.

\subsection{Comparisons between different models}

The box and whisker plots in Figs. 6 and 7 show the change in streamflow in the two periods (the first $15 \mathrm{yr}$ after the 1983 bushfires and after $15 \mathrm{yr}$ post-bushfire) estimated by the three hydrological models (AWRA-L, Xinanjiang and GR4J model) for the three 20 catchments (Latrobe at Noojee, Starvation Creek and Yarra River at Little Yarra) in mm and percentage change respectively. The horizontal line in each box shows the median of the modelling results over the three models, the upper and lower envelops show the 75th and 25th percentile values and the upper and lower whiskers show the 95th and 5 th percentile values.

25 There are some differences in the vegetation cover and climate variability impacts estimated by the three models for the three study catchments (Figs. 6 and 7). The maximum difference between the modelling results during the first $15 \mathrm{yr}$ due to vegetation change for the three models are $29 \mathrm{~mm}(95 \mathrm{~mm}$ to $66 \mathrm{~mm}), 44 \mathrm{~mm}$ (155 mm to

\section{HESSD}

10, 4397-4437, 2013

Impact of bushfire and climate

variability on

streamflow

Y. Zhou et al.

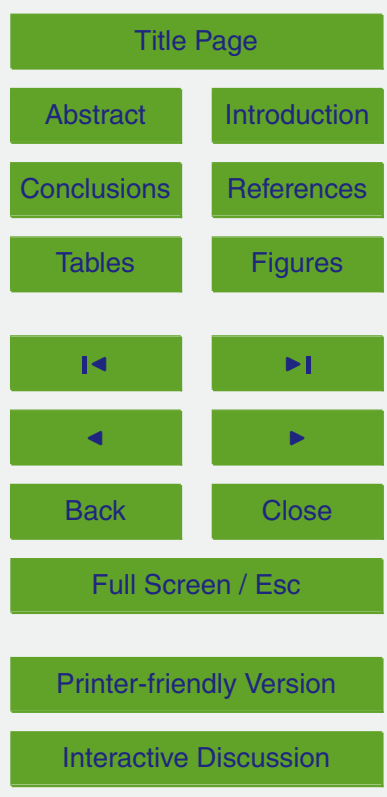


$110 \mathrm{~mm}$ ) and $18 \mathrm{~mm}(38 \mathrm{~mm}$ to $20 \mathrm{~mm}$ ) for Latrobe at Noojee, Starvation Creek and Yarra River at Little Yarra catchments respectively. This maximum difference is equivalent to $9.5 \%, 10.7 \%$ and $5.9 \%$ relative to pre-bushfire period streamflow for the three catchments, respectively. After $15 \mathrm{yr}$ post-bushfire, the maximum difference between 5 the modelling results for the three models is $43 \mathrm{~mm}(48 \mathrm{~mm}$ to $4 \mathrm{~mm}), 27 \mathrm{~mm}(48 \mathrm{~mm}$ to $21 \mathrm{~mm})$ and $37 \mathrm{~mm}(8 \mathrm{~mm}$ to $-29 \mathrm{~mm})$. This maximum difference is equivalent to $14.3 \%, 6.6 \%$ and $12.2 \%$ relative to pre-bushfire period streamflow for the three catchments, respectively. The differences between the results from the three hydrological models can be attributed to differences in the conceptual complexity, structure, param10 eter numbers and transposability of model parameters. This is further discussed in Sect. 4.4.

All results from the three models show reasonable agreement with each other. In first $15 \mathrm{yr}$ after bushfires, vegetation dynamics show much larger impacts on streamflow than climate variability, and result in the substantial increase in streamflow. Streamflow in Starvation Creek catchment show much larger increase than that in Latrobe at Noojee catchment which in turn shows larger increase than in Yarra River at Little Yarra catchment. It seems to be inversely related to percentage of ash disturbance. Yarra River at Little Yarra catchment with the highest percentage of ash disturbance (shown in Fig. 2a) has the lowest increase in streamflow.

After $15 \mathrm{yr}$ post-bushfire, vegetation impacts on streamflow are negligible for the post 1999 period (after $15 \mathrm{yr}$ post-bushfire), when compared to the impacts in the first $15 \mathrm{yr}$ post-bushfire. During this period, there is a large reduction in streamflow due to substantial reduction in mean annual rainfall of $217 \mathrm{~mm}, 221 \mathrm{~mm}$ and $150 \mathrm{~mm}(15.4 \%$, $13.6 \%$ and $1.2 \%$ ) compared to the pre-bushfire period for Latrobe at Noojee, Starvation Creek and Yarra River at Little Yarra catchments, respectively. The differences in the results from the three models are partially due to the uncertainties in hydrological model structure and parameterisation.

\section{HESSD}

10, 4397-4437, 2013

Impact of bushfire and climate

variability on

streamflow

Y. Zhou et al.

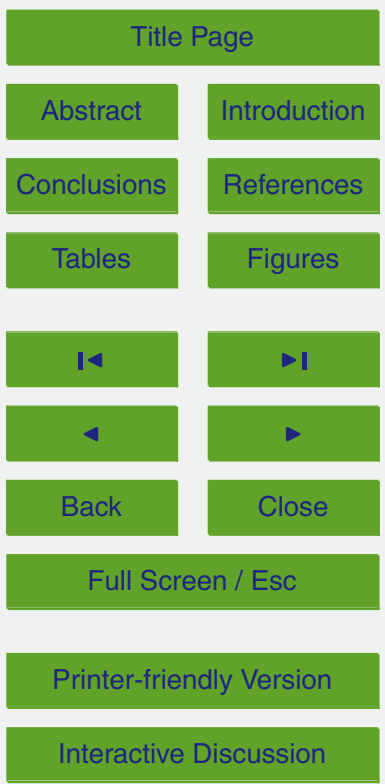




\subsection{Discussion}

The applicability of hydrological modelling to quantify vegetation change and climate variability impacts on streamflow mainly depends on how the model parameters are calibrated and how they are transferred from calibration period to simulation period. It 5 is important to investigate the transposability of model parameters in time (i.e. to make sure that their estimation is not dependent on climate characteristics of the calibration periods). This can provide us with a better understanding of uncertainty associated with using hydrological models for quantifying bushfire and climatic variability impacts on streamflow. The results will also provide confidence in the climate variability and 10 vegetation change impact assessments based on hydrological modelling. To investigate the model transposability, four median-size catchments close to the three study catchments varying from $109 \mathrm{~km}^{2}$ to $1080 \mathrm{~km}^{2}$ were selected. All these four catchments have long period of observed streamflow data, are unregulated and are not subject to vegetation changes (Table 6). The GR4J model is used for the parameter transpos-

15 ability modelling experiments. The pre-bushfire period (1975-1982) is used for model calibration and three post-bushfire periods, 1983-2009, 1983-1998 and 1999-2009, are used for model validation.

The modelling results show that the GR4J model generally performs reasonably well both in the calibration and validation periods. For all the four catchments, the NSE values obtained for the validation periods are similar to those obtained for the calibration period. The differences between the $B$ values for the calibration and validation periods for all the four catchments are also small. First, the $B$ values obtained in the whole validation period (1983-2009) are compared to those obtained in the calibration period (1975-1982). For the 405205 catchment, the $B$ value obtained in the validation period is actually smaller (about 0.06 ) than that obtained in the calibration period and for the other three catchments, the $B$ values obtained in the validation period are slightly larger ( $B$ increase of about $0.03-0.07$ ) than those obtained in the calibration period. Second, the validation period is split into two: $1983-1998$ and 1999-2009, to match the two
HESSD

$10,4397-4437,2013$

Impact of bushfire and climate

variability on

streamflow

Y. Zhou et al.

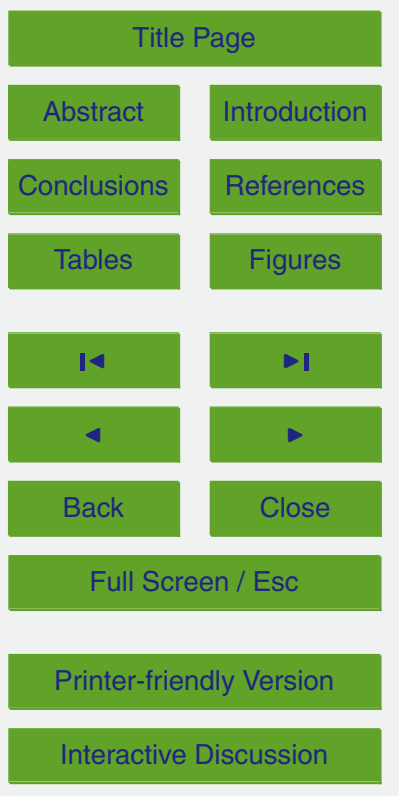


post-bushfire periods used for bushfire impact analysis. The bias obtained in the first validation period (1983-1998) is similar to that obtained in the second validation period (1999-2004) for catchment 405205, but is about 0.03-0.12 smaller for other three catchments. The differences in $B$ between the calibration period and the first validation 5 period range between $0.01-0.06$ and the differences in $B$ between the calibration period and the second validation period range between $0.07-0.11$. The slightly higher $B$ values in the second validation period can be partly caused due to the larger climatic differences between the two periods (the 1999-2009 period is about $15 \%$ drier than the 1975-1982 period for these four catchments). This is in agreement with the finding 10 of some recent papers which indicate that there can be a reduction in model predictive capability when transferring calibrated model parameters from wet to dry periods (Vaze et al., 2010; Merz et al., 2011; Coron et al., 2012). The modelling experiments carried out in this study suggest that the uncertainty of transferring model parameters from the calibration period to the first test period (the first $15 \mathrm{yr}$ post-bushfire) is very small (difference in $B$ values between calibration and validation periods of $0.1-0.6$ ) and it increases slightly when transferring the calibrated parameters from the calibration period to the second test period (after the first $15 \mathrm{yr}$ post-bushfire). The 0.01-0.06 changes in $B$ from the calibration period to the first test period are much smaller than the impacts of the 1983 bushfire and the $0.07-0.11$ changes in $B$ from the calibration period to the second test period are also smaller than the climate change impact on streamflow in the second period (Table 5). The results for these four neighbouring catchments provide confidence in the hydrological modelling results quantifying the impacts of climate variability and vegetation change for the three study catchments.

The hydrological modelling results for all the three catchments indicate that there is 25 a substantial increase in streamflow in the first $15 \mathrm{yr}$ after the 1983 bushfires that is not attributable to climate alone. An increase in streamflow in the early years is consistent with conceptual models of leaf area loss/ET decrease, as nearly $19 \%$ to $84 \%$ of the forest cover in the three catchments was burnt in the 1983 bushfires. A caveat there though is that uncertainties in the fire intensities mean that we cannot be sure how

\section{HESSD}

10, 4397-4437, 2013

Impact of bushfire and climate

variability on

streamflow

Y. Zhou et al.

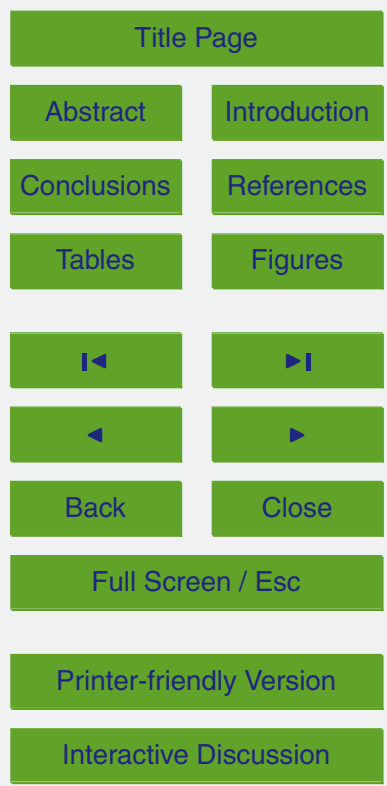

4415 
much canopy area was affected. The Bosch and Hewlett (1982) review of forest cover change and streamflow found that streamflow response to cover changes of $<20 \%$ of catchment area could not be verified statistically.

The only hypothesis that supports the persistence of such increases after the first $5 \quad 3-5 \mathrm{yr}$ is disturbance by subsequent logging activities (Fig. 1), which almost doubles the fire kill area for the Latrobe and Yarra catchments, and results in the largest area of ash disturbance at Starvation Creek. However, the large streamflow increases for Starvation Creek that can be attributed to the fire appear to be highly disproportionate to the fire-related mortality area of only $3 \%$, and even once logging begins at this 10 catchment the response apportioned to vegetation change appears to be quite high for the area affected.

There are two issues that require consideration if we are to accept the modelling results as representing real effects. Firstly, what processes could drive such large flow increase at Starvation Creek with a 3\% mortality area, and secondly, how would the 15 balance of disturbance/regrowth over two decades play out in streamflow changes for all catchments?

For Starvation Creek, the only plausible explanation for the early post-fire years is that there was a significant impact in the non-ash species that resulted in high canopy loss and low ET immediately after the fire. Rainfall in 1983 and 1984 was 1453 and 20 $1541 \mathrm{~mm}$, respectively (long term SILO mean is $1565 \mathrm{~mm}$ ), which means there was a significant supply of potential water for streamflow. The catchment received $979 \mathrm{~mm}$ of rainfall between the fire (16 February) and 30 September 1983. Little ET could be expected from burnt areas during this period. An increase of this magnitude is less than that measured by Lane et al. (2006) for stands with almost complete canopy loss

(but extensive alpine ash mortality). It is also consistent with early increases predicted and observed by Lane et al. (2010) using physically-based modelling for the $1533 \mathrm{~km}^{2}$ Mitta Mitta catchment after the 2003 fires. Further, the dry period that preceded the Ash Wednesday fire was relatively short (rainfall in 1981 was $1515 \mathrm{~mm}$ and in 1982 it was $1243 \mathrm{~mm}$ ), suggesting that soil moisture deficits were not extreme.
HESSD

$10,4397-4437,2013$

Impact of bushfire

and climate

variability on

streamflow

Y. Zhou et al.

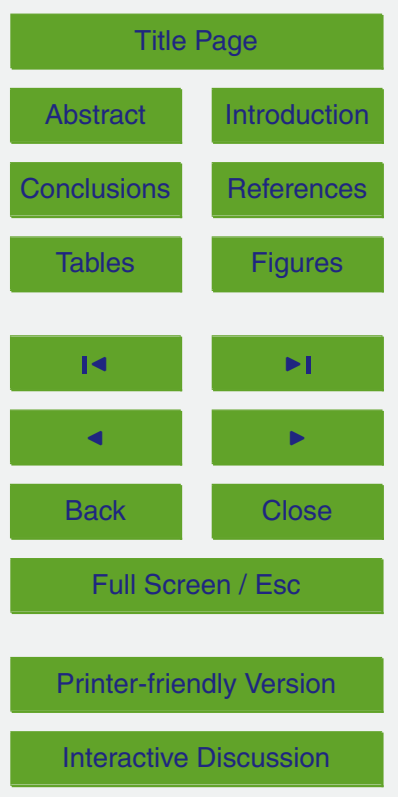


There is current unpublished research into the ecohydrology of recovering mixed species eucalypt stands that suggest water use may be high in early post fire years once seedling recruitment and leaf recovery begins $(R$. Nolan, personal communication, 2012). This would act to mitigate against the flow increases at Starvation Creek 5 after 1984, but it may be that the post-fire rainfall (almost $1000 \mathrm{~mm}$ ) recharged deep stores that fed the streamflow for some years. The low ash mortality also means there would be little effect in subsequent years of high water-using regrowth with an origin in 1983 or 1984 . This may in part explain the scale of flow increases in the late 1990s.

The water gain/loss over time is the balance between lower and higher rates of ET 10 relative to the pre-disturbance values as the ash stands recover. The conceptual model for ash ET is a decrease for $1-5$ yr followed by an increase until age 25-30, then a return toward equilibrium rates over many decades. The fire disturbance followed by logging would result in different areas of the catchments in varying states of ET. It is notable that the three models show either flow decreases or (for Latrobe) a very small

increase for the post 1998 period. This accords (at least relatively) with a trend toward high water use in the latter part of the record. However, the modelling suggests in some instances that the streamflow changes are due to climate rather than vegetation dynamics.

Finally, there is a background vegetation-hydrologic dynamic that may or may not 20 have been dealt with by the calibration. The ash that was not subjected to fire or logging is ageing, and according to the Kuczera and Watson curves, is on a trajectory of increasing streamflow. Over the period of interest (1983-2000, 2004, 2007) we could expect flow increases in the order of $4 \%$ for 1983-1998 for Latrobe and Yarra catchments and $8 \%$ for Starvation Creek from the remaining ash stands, plus further increases for the post 1998 period. It could be argued that the good calibration results reflect the models' ability to deal with this issue. If this is not the case then some of the flow increases may have been inflated in the first post-fire period, and perhaps decreases masked subsequently.
HESSD

$10,4397-4437,2013$

Impact of bushfire and climate

variability on streamflow

Y. Zhou et al.

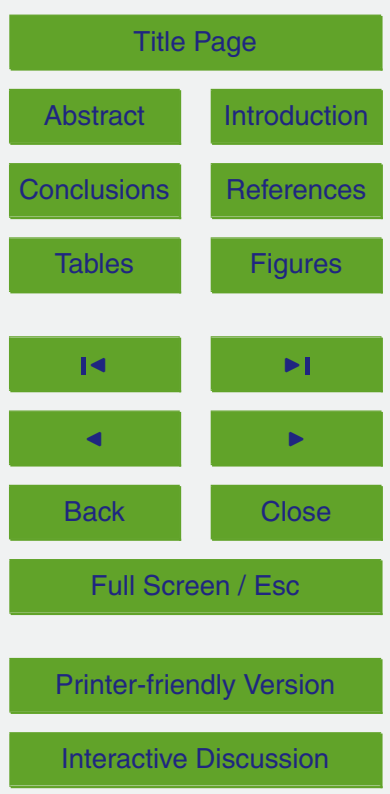


Overall, the modelling results are plausible from a process perspective for the Latrobe and Yarra catchments, but explaining the large effect at Starvation Creek is contingent on significant (and unknown) loss of canopy from non-ash species. Generalising these results for bushfire impacts is difficult. As stated, the lack of information on fire 5 severity and canopy loss is sketchy for this fire event, so the exact vegetation impact is not known. There were two quite distinct patterns of rainfall over the period of interest, with a relatively wet period coinciding with the first analysis period (1983-1998) followed by a sequence of dry years. Finally, the issue of soil moisture deficits at the time of the fire and the subsequent rainfall in the next 6-9 months before significant vegetation recovery is likely to be a large lever on flow responses.

\section{Conclusions}

The hydrological modelling results for all the three catchments suggest that there was a substantial increase in streamflow in the first $15 \mathrm{yr}$ after the 1983 bushfires that could not be accounted for by climate effects. There is a reasonable agreement between the bushfire and climate variability impacts on streamflow results for this first post-fire period from the three hydrological models for the Latrobe at Noojee, Starvation Creek and Yarra River at Little Yarra catchments. We hypothesise the flow increases were mainly caused by the loss of leaf area and tree morality because of the bushfires and associated reduction in interception and actual evapotranspiration. These increases are in agreement with the general pattern of significant annual water yield increase following forest disturbance reported in the literature, but the persistence of the inflow increases appears to be related to logging in the 1990s and early 2000s. The modelled flow responses for the post-1998 period are attributed to a combination of vegetation recovery after disturbance and climate factors as the lengthy drought developed. Flow decreases driven by vegetation are plausible for areas of regenerating mountain ash.

Uncertainties in this study arise from transferring of model parameters from calibration to test periods, imprecise knowledge on fire severity and associated impact
HESSD

$10,4397-4437,2013$

Impact of bushfire and climate

variability on

streamflow

Y. Zhou et al.

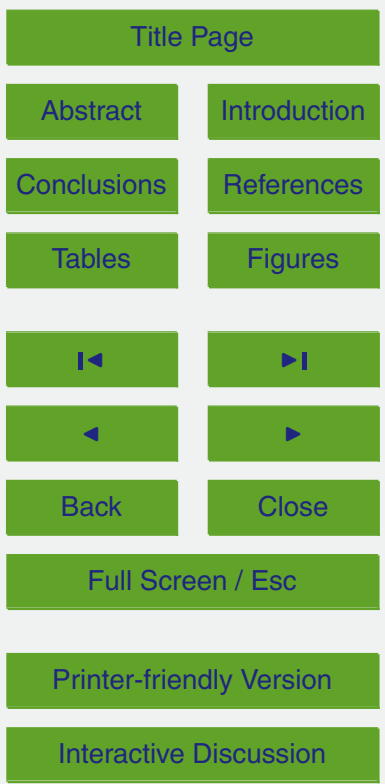


on non-ash species, the interplay of fire recovery, logging effects and a background vegetation-flow dynamic in these forests, and from distinct climate regimes over the period of the study. However the modelling has produced some interesting insights into fire and logging effects in SE Australian forests.

5 Acknowledgements. The first author acknowledges the Chinese Scholarship Council for supporting her Ph.D. Study at the Australian Commonwealth Scientific and Research Organization (CSIRO). This work was carried out in the Water for Healthy Country (WFHC) National Research Flagship. The authors would like to thank Andrew Davidson, Jorge Pena Arancibia, two anonymous reviewers and the editor for their useful comments and suggestions.

\section{References}

Andréassian, V.: Waters and forests: from historical controversy to scientific debate, J. Hydrol., 291, 1-27, 2004.

Andréassian, V., Hall A., Chahinian, N., and Schaake J.: Introduction and synthsis: why should hydrologists work on a large number of basin data sets? in: Large Sample Basin Experiments for Hydrological Model Parameterization: Results of the Model Parameter Experiment - MOPEX, IAHS Press, Wallingford, UK, 307, 1-5, 2006.

Bosch, J. M. and Hewlett, J. D.: A review of catchment experiments to determine the effect of vegetation change on water yield and evapotranspiration, J. Hydrol., 55, 3-23, 1982.

Brown, A. E., Zhang, L., McMahon, T. A., Western, A. W., and Vertessy, R. A.: A review of paired catchment studies for determining change in water yield resulting from changes in vegetation, J. Hydrol., 310, 28-61, 2005.

Brown, J. A. H.: Hydrologic effects of a bushfire in a catchment in south-eatern New South Wales, J. Hydrol., 15, 77-96, 1972.

Buckley, T. N., Turnbull, T. L., Pfautsch, S., Gharun, M., and Adams, M. A.: Differences in water use between mature and post-fire regrowth stands of subalpine Eucalyptus delegatensis, Forest Ecol. Manag., 270, 1-10, 2012.

Chau, K. W.: Particle swarm optimization training algorithm for ANNs in stage prediction of Shing Mum River, J. Hydrol., 329, 363-367, 2006.
HESSD

10, 4397-4437, 2013

Impact of bushfire

and climate

variability on

streamflow

Y. Zhou et al.

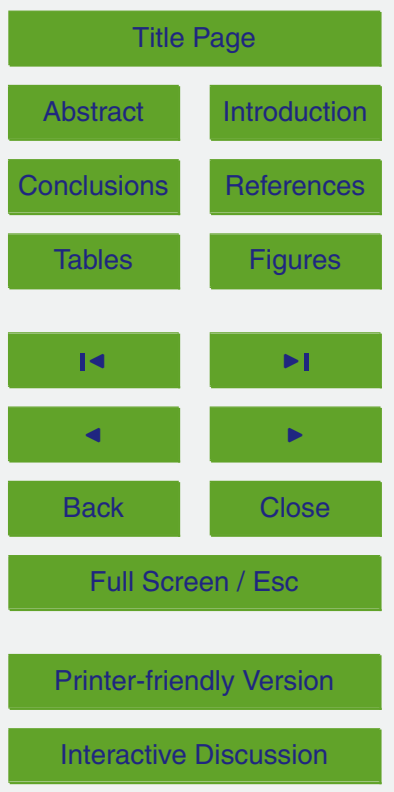


Cheng, C. T., Ou, C. P., and Chau, K. W.: Combining a fuzzy optimal model with a genetic algorithm to solve multi-objective rainfall-runoff model calibration, J. Hydrol., 268, 1-4, 7286, 2002.

Chiew, F. H. S.: Estimation of rainfall elasticity of streamflow in Australia, Hydrolog. Sci. J., 51, 613-625, 2006.

Christensen, P. E., Recher, H. F., and Hoare, J.: Responses of open forests (dry sclerophyll forests) to fire regimes, in: Fire and the Australian Biota, edited by: Gill, A. M., Groves, R. H., and Noble, I. R., Australian Academy of Science, Canberra, 367-393, 1981.

Cornish, P. M.: The effects of logging and forest regeneration on water yields in a moist eucalypt forest in New South Wales, Australia, J. Hydrol., 150, 301-322, 1993.

Cornish, P. M. and Vertessy, R. A.: Forest age-induced changes in evapotranspiration and water yield in a eucalypt forest, J. Hydrol., 242, 43-63, 2001.

Coron, L., Andréassian V., Perrin, C., Lerat, J., Vaze, J., Bourqui, M., and Hendrickx, F.: Crash testing hydrological models in contrasted climate conditions: an experiment on 216 Australian catchments, Water Resour. Res., 48, W05552, doi:05510.01029/2011WR011721, 2012.

Dam, J. C.: Impacts of Climate Change and Variability on Hydrological Regimes, Cambridge University Press, Cambridge, UK, 1999.

Eberhart, R. C. and Kennedy, J.: A new optimizer using particle swarm theory, in: Sixth International Symposium on Micro Machine and Human Science, Nagoya Municipal Industrial Research Institute, Nagoya, Japan, 4-6 October 1995, 39-43, 1995.

Gill, A. M.: Stems and fires, Plant Stems, Physiology and Functional Morphology, edited by: Gartner, B. L., Academic Press, San Diego, 323-342, 1995.

Gill, M. K., Kaheil, Y. H., Khalil, A., McKee, M., and Bastidas, L.: Multiobjective particle swarm optimization for parameter estimation in hydrology, Water Resour. Res., 42, W07417, doi:10.1029/2005WR004528, 2006.

Haydon, S. R., Benyon, R. G., and Lewis, R.: Variation in sapwood area and throughfall with forest age in mountain ash (Eucalyptus regnans), J. Hydrol., 187, 351-366, 1996.

Helvey, J. D.: Effects of a north central Washington wildfire on runoff and sediment production, Water Resour. Bull., 16, 628-634, 1980.

so Jayawardena, A. W. and Zhou, M. C.: A modified spatial soil moisture storage capacity distribution curve for the Xinanjiang model, J. Hydrol., 227, 93-113, 2000.
HESSD

10, 4397-4437, 2013

Impact of bushfire

and climate

variability on

streamflow

Y. Zhou et al.

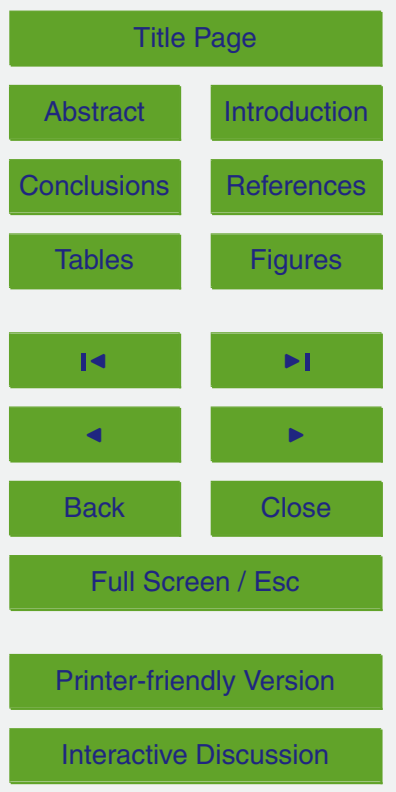


Jeffrey, S. J., Carter, J. O., Moodie, K. B., and Beswick, A. R.: Using spatial interpolation to construct a comprehensive archive of Australian climate data, Environ. Modell. Softw., 16, 309-330, 2001.

Kiem, A. S. and Franks, S. W.: On the identification of ENSO-induced rainfall and runoff vari5 ability: A comparison of methods and indices, Hydrolog. Sci. J., 46, 715-727, 2001.

Kuczera, G. A.: Prediction of water yield reductions following a bushfire in ash-mixed species eucalypt foreset, J. Hydrol., 94, 215-236, 1987.

Lane, P. N. J., Best, A. E., Hickel, K., and Zhang, L.: The response of flow duration curves to afforestation, J. Hydrol., 310, 253-265, 2005.

10 Lane, P. N. J., Sheridan, G. J., and Noske, P. J.: Changes in sediment loads and discharge from small mountain catchments following wildfire in south eastern Australia, J. Hydrol., 331, 495-510, 2006.

Lane, P. N. J., Feikema, P. M., Sherwin, C. B., Peel, M. C., and Freebairn, A. C.: Modelling the long term water yield impact of wildfire and other forest disturbance in Eucalypt forests,

Lane, P. N. J., Sheridan, G. J., Noske, P. J., Sherwin, C. B., Costenaro, J. L., Nyman, P., and Smith, H. G.: Fire effects on forest hydrology: lessons from a multi-scale catchment experiment in SE Australia, in: Revisiting Experimental Catchment Studies in Forest Hydrology, IAHS Publ. 353, Wallingford, Oxfordshire, UK, 137-143, 2012.

Lerat, J., Perrin, C., Andréassian, V., Vaze, J., Perraud, J. M., Ribstein, P., and Loumagne, C.: Do internal flow measurements improve the calibration of semidistributed rainfall-runoff models?, Water Resour. Res., 48, W02511, doi:10.1029/2010WR010179, 2012.

Langford, K. J.: Change in yield of water following a bushfire in a forest of Eucalypt regnans, J. Hydrol., 29, 87-114, 1976.

Li, L. J., Zhang, L., Wang, H., Wang, J., Yang, J. W., Jiang, D. J., Li, J. Y., and Qin, D. Y.: Assessing the impact of climate variability and human activities on streamflow from the Wuding River basin in China, Hydrol. Process., 21, 3485-3491. doi:10.1002/hyp.6485, 2007.

Li, H. Y., Zhang, Y. Q., Vaze, J., and Wang, B. D.: Separating effects of vegetation change and climate variability using hydrological modelling and sensitivity-based approaches, J. Hydrol., 420-421, 403-418, 2012.

Li, Z., Liu, W. Z., Zhang, X. C., and Zheng, F. L.: Impacts of land use change and climate variability on hydrology in an agricultural catchment on the Loess Plateau of China, J. Hydrol., 377, 35-42, 2009.
HESSD

10, 4397-4437, 2013

Impact of bushfire

and climate

variability on

streamflow

Y. Zhou et al.

Title Page

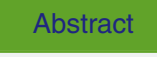

Introduction

Conclusions

Tables

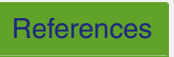

Figures

14

$\rightarrow$

$\triangleleft$

Back

$\checkmark$

Close

Full Screen / Esc

Printer-friendly Version

Interactive Discussion 
Mannik, R. D., Hill, P. I., Murphy, R. E., Herron, A., and Moran R.: Estimating the change in streamflow resulting from the 2003 and 2006/07 bushfires in south eastern Australia, in: Proceedings of the 32nd Hydrology and Water Resources Symposium, Newcastle, Australia, 30 November-3 December 2009, 1666-1677, 2009.

5 Merz, R., Parajka, J., and Blöschl, G.: Time stability of catchment model parameters: implications for climate impact analyses, Water Resour. Res., 47, W02531, doi:10.1029/2010WR009505, 2011.

Morton, F. I.: Operational estimates of areal evapo-transpiration and their significance to the science and practice of hydrology, J. Hydrol., 66, 1-76, 1983.

10 Nash, J. E. and Sutcliffe, J. V.: River flow forecasting through conceptual models part I - a discussion of principles, J. Hydrol., 10, 282-290, 1970.

Perrin, C., Michel, C., and Andréassian L.: Improvement of a parsimonious model for streamflow simulation, J. Hydrol., 279, 1-76, 2003.

Post, D. A. and Jakeman, A. J.: Relationships between catchment attributes and hydrological

15 response characteristics in small Australian mountain ash catchments, Hydrol. Process., 10, 877-892, 1996.

Purdie, R. W. and Slatyer, R. O. Vegetation succession after fire in sclerophyll woodland communities in south-eastern Australia, Aust. J. Ecol., 1, 233-236, 1976.

Scott, D. F.: The hydrological effects of fire in South African mountain catchments, J. Hydrol. 150, 409-432, 1993.

Scott, D. F.: The contrasting effects of wildfire and clearfelling on the hydrology of a small catchment, Hydrol. Process., 11, 543-555, 1997.

Smith, H. G., Sheridan, G. J., Lane, P. N. J., and Bren, L. J.: Wildfire and salvage harvesting effects on runoff generation and sediment exports from radiata pine and eucalypt forest catchments, south-eastern Australia, Forest Ecol. Manag., 261, 570-581, 2011.

Stone, R. and Auliciems, A.: SOI phase relationships with rainfall in eastern Australia, Int. J. Climatol., 12, 625-636, 1992.

Tan, K. S., Flower, D. J. M., and Flowers, D. M.: An event runoff coefficient approach for assessing changes in short-term catchment runoff following bushfires, in: Proceedings of the 33rd

30 Hydrology and Water Resources Symposium, Brisbane, Australia, 26 June-1 July, 15221529, 2011.

Tomer, M. D. and Schilling, K. E.: A simple approach to distinguish land-use and climate-change effects on watershed hydrology, J. Hydrol., 376, 24-33, 2009.

Impact of bushfire

and climate

variability on

streamflow

Y. Zhou et al.

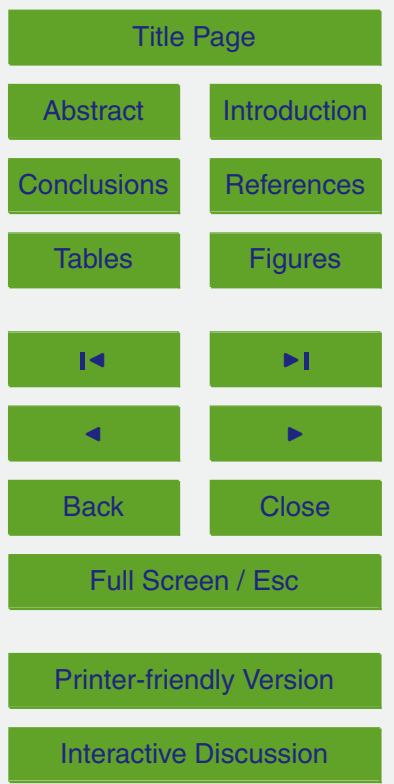


Tuteja, N. K., Vaze, J., Teng, J., and Mutendeudzi, M.: Partioning the effects of pine plantations and climate variability on runoff from a large catchment in southeastern Australia, Water Resour. Res., 43, W08415, doi:10.1029/2006WR005016, 2007.

Van Dijk, A. I. J. M.: The Australian Water Resources Assessment System, Technical Report 3. 5 Landscape Model (version 0.5) Technical Description, CSIRO, Canberra, Australia, 110 pp., 2010.

Vaze, J. and Chiew, F. H. S.: Study of pollutant washoff from small impervious experimental plots, Water Resour. Res., 39, 1160, doi:10.1029/2002WR001786, 2003.

Vaze, J. and Teng, J.: Future climate and runoff projections across New South Wales, Australia - results and practical applications, Hydrol. Process., 25, 18-35, doi:10.1002/hyp.7812, 2011.

Vaze, J., Barnett, P., Beale, G. T. H., Dawes, W., Evans, R., Tuteja, N. K., Murphy, B., Geeves, G., and Miller, M.: Modelling the effects of landuse change on water and salt delivery from a catchment affected by dryland salinity in south-east Australia, Hydrol. Process., 18, 1613-1637, 2004.

Vaze, J., Chiew, F. H. S., Perraud, J. M., Viney, N., Post, D. A., Teng, J., Wang, B., Lerat, J., and Goswami, M.: Rainfall-runoff modelling across southeast Australia: datasets, models and results, Australian Journal of Water Resources, 14, 101-116, 2010a.

Vaze, J., Post, D. A., Chiew, F. H. S., Perraud, J. M., Viney, N. R., and Teng J.: Climate nonstationarity - validity of calibrated rainfall-runoff models for use in climate change studies, $\mathrm{J}$. Hydrol., 394, 447-457, 2010b.

Vaze, J., Davidson, A., Teng, J., and Podger, G.: Impact of climate change on water availability in the Macquarie-Castlereagh river basin in Australia, Hydrol. Process., 25, 2597-2612, doi:10.1002/hyp.8030, 2011.

Verdon-Kidd, D. C. and Kiem, A. S.: Nature and causes of protracted droughts in southeast Australia: comparison between the Federation, WWII, and Big Dry droughts, Geophys. Res. Lett., 36, L22707, doi:10.1029/2009GL041067, 2009

Vertessy, R. A., Benyon, R. G., O'Sullivan, S. K., and Gribben, P. R.: Relationships between stem diameter, sapwood area, leaf area and transpiration in a young mountain ash forest, 30 Tree Physiol., 15, 559-568, 1995.

Vertessy, R. A., Hatton, T. J., Benyon, R. G., and Dawes, W. R.: Long-term growth and water balance predictions for a mountain ash (Eucalyptus regnans) forest catchment subject to clear-felling and regeneration, Tree Physiol., 16, 221-232, 1996.
HESSD

$10,4397-4437,2013$

Impact of bushfire

and climate

variability on

streamflow

Y. Zhou et al.

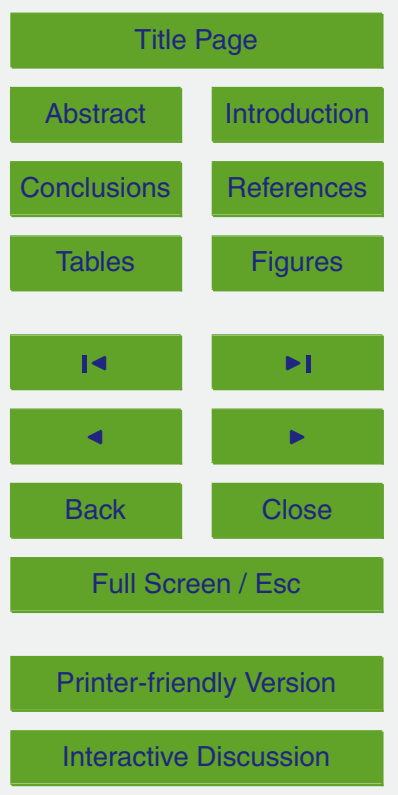


Vertessy, R. A., Watson, F. G. R., and O'Sullivan, S. K.: Factors determining relations between stand age and catchment water balance in mountain ash forests, Forest Ecol. Manag., 143, 13-26, 2001.

Viney, N. R., Perraud, J., Vaze, J., Chiew, F. H. S., Post, D. A., and Yang, A.: The usefulness of 5 bias constraints in model calibration for regionalisation to ungauged catchments, 18th World IMACS/MODSIM Congress, Cairns, Australia, 13-17 July 2009, 3421-3427, 2009.

Vivian, L. M., Cary, G. J., Bradstock, R. A., and Gill, A. M.: Influence of fire severity on the regeneration, recruitment and distribution of eucalypts in the Cotter River Catchment, Australian Capital Territory, Austral. Ecol., 33, 55-67, 2008.

10 Watson, F. G. R., Verteesy, R. A., and Grayson, R. B.: Large-scale modeling of forest hydrological processes and their long-term effect on water yield, Hydrol. Process., 13, 689-700, 1999.

Zhang, Y. Q. and Chiew, F. H. S.: Relative merits of different methods for runoff predictions in ungauged catchments, Water Resour. Res., 45, W07412, doi:10.1029/2008WR007504, 152009.

Zhao, R. J.: The Xinanjiang model applied in China, J. Hydrol., 135, 371-381, 1992.

Zhao, R. J., Zhang, Y. L., Fang, L. R., Liu, X. R., and Zhang, Q. S.: The Xinanjiang model, in: Hydrological Forecasting Proceedings Oxford Symposium, 15-18 April, 351-356, 1980.

\section{HESSD}

10, 4397-4437, 2013

Impact of bushfire

and climate

variability on

streamflow

Y. Zhou et al.

Title Page

Abstract

Introduction

Conclusions

Tables

References

Figures

14

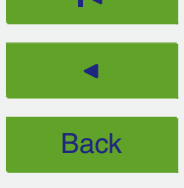

$>1$

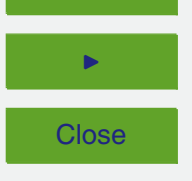

Full Screen / Esc

Printer-friendly Version

Interactive Discussion 
HESSD

10, 4397-4437, 2013

Impact of bushfire and climate

variability on

streamflow

Y. Zhou et al.

Table 1. Catchments attributes and calibration and test periods.

\begin{tabular}{llllllll}
\hline $\begin{array}{l}\text { Catchment Catchment Names } \\
\text { Code }\end{array}$ & $\begin{array}{l}\text { Burnt } \\
\text { Area } \\
\text { Percentage } \\
(\%)\end{array}$ & $\begin{array}{l}\text { Catchment } \\
\text { Area } \\
\left(\mathrm{km}^{2}\right)\end{array}$ & $\begin{array}{l}\text { Area Burnt } \\
\left(\mathrm{km}^{2}\right)\end{array}$ & $\begin{array}{l}\text { Period of } \\
\text { record }\end{array}$ & $\begin{array}{l}\text { Calibration } \\
\text { Period }\end{array}$ & $\begin{array}{c}\text { Test period } \\
\end{array}$ \\
\hline 226205 & Latrobe at Noojee & 18.52 & 292.91 & 54.25 & $1966-2007$ & $1967-1982$ & $1983-2007$ \\
229109 & Starvation Creek & 84.12 & 31.47 & 26.47 & $1973-2004$ & $1974-1982$ \\
229214 & Yarra River at Little Yarra & 45.58 & 149.43 & 68.1 & $1971-2000$ & $1972-1982$ & $1983-2000$ \\
\hline
\end{tabular}

Title Page

Abstract Introduction

Conclusions

References

Tables

Figures

14

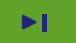

4

Back

Close

Full Screen / Esc

Printer-friendly Version

Interactive Discussion 
Table 2. Mean annual streamflow, rainfall and areal potential evapotranspiration (APET) for different periods for the three catchments.

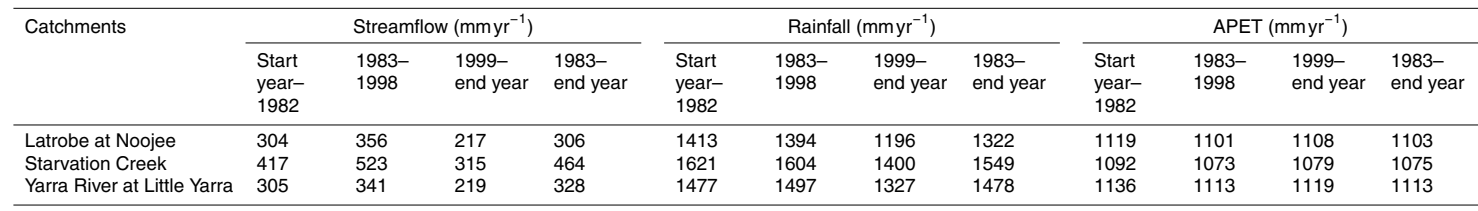

"start year" is the calibration start year of streamflow record.

"end year" is the end year of streamflow record.

HESSD

10, 4397-4437, 2013

Impact of bushfire and climate

variability on

streamflow

Y. Zhou et al.

Title Page

Abstract

Introduction

Conclusions

References

Tables

Figures

14

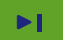

4

Back

Close

Full Screen / Esc

Printer-friendly Version

Interactive Discussion 


\section{HESSD}

10, 4397-4437, 2013

Impact of bushfire and climate

variability on

streamflow

Y. Zhou et al.

Table 3. Hydrological model calibration results for the three catchments.

\begin{tabular}{llllllll}
\hline \multirow{2}{*}{$\begin{array}{l}\text { Catchment Catchment } \\
\text { Code }\end{array}$} & Names & AWRA-L & \multicolumn{2}{c}{ XAJ } & \multicolumn{2}{c}{ GR4J } \\
& NSE & B (\%) & NSE & B (\%) & NSE & B (\%) \\
\hline 226205 & Latrobe at Noojee & 0.78 & -0.76 & 0.78 & 0.66 & 0.71 & -0.57 \\
229109 & Starvation Creek & 0.84 & -0.20 & 0.80 & 2.65 & 0.67 & 2.29 \\
229214 & Yarra River at Little Yarra & 0.85 & 0.39 & 0.85 & 1.80 & 0.83 & -0.31 \\
\hline
\end{tabular}

Title Page

Abstract Introduction

Conclusions

References

Tables

Figures

14

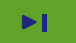

4

Back

Close

Full Screen / Esc

Printer-friendly Version

Interactive Discussion 
Table 4. Overview of the characteristics for the three hydrological models.

\begin{tabular}{|c|c|c|c|}
\hline Characteristics & AWRA-L & XAJ & GR4J \\
\hline $\begin{array}{l}\text { Number of free } \\
\text { parameters }\end{array}$ & 17 & 14 & 4 \\
\hline Interception & An interception store & No interception store & $\begin{array}{l}\text { A zero capacity interception } \\
\text { store }\end{array}$ \\
\hline Evapotranspiration & $\begin{array}{l}\text { Rainfall interception evaporation; } \\
\text { Soil evaporation; } \\
\text { Open water evaporation; } \\
\text { Groundwater evaporation; } \\
\text { Transpiration }\end{array}$ & $\begin{array}{l}\text { Three-layer } \\
\text { evapotranspiration }\end{array}$ & One layer soil evaporation \\
\hline Runoff production & $\begin{array}{l}\text { Three layers soil moisture } \\
\text { accounting store; } \\
\text { Infiltration excess surface runoff and } \\
\text { saturation excess runoff; } \\
\text { Two hydrological response units }\end{array}$ & $\begin{array}{l}\text { A soil moisture account- } \\
\text { ing store; } \\
\text { Saturation excess runoff; }\end{array}$ & $\begin{array}{l}\text { A soil moisture accounting } \\
\text { store; } \\
\text { Infiltration excess surface } \\
\text { runoff and saturation excess } \\
\text { runoff }\end{array}$ \\
\hline Routing & No routing store & $\begin{array}{l}\text { lag-and-route routing; } \\
\text { A nonlinear routing store }\end{array}$ & $\begin{array}{l}\text { Two unit hydrographs; } \\
\text { A nonlinear routing store }\end{array}$ \\
\hline Source & Van Dijk (2010) & Zhao (1992) & Perrin et al. (2003) \\
\hline
\end{tabular}

HESSD

10, 4397-4437, 2013

Impact of bushfire and climate variability on streamflow

Y. Zhou et al.

Title Page

Abstract Introduction

Conclusions

References

Tables

Figures

14

I

4

Back

Close

Full Screen / Esc

Printer-friendly Version

Interactive Discussion 
Table 5. Effects of bushfire and climate variability on the mean annual streamflow for the three catchments.

\begin{tabular}{|c|c|c|c|c|c|c|c|c|c|c|c|c|c|c|c|}
\hline \multirow[b]{3}{*}{ Catchment } & \multirow{3}{*}{$\begin{array}{l}\text { Periods } \\
\text { (post-bushfire) }\end{array}$} & \multirow{2}{*}{\multicolumn{2}{|c|}{$\begin{array}{c}\Delta Q_{\text {tot }} \\
\text { (relative to pre-bushfire) }\end{array}$}} & \multicolumn{4}{|c|}{ AWRA_L } & \multicolumn{4}{|c|}{ XAJ } & \multicolumn{4}{|c|}{ GR4J } \\
\hline & & & & \multicolumn{2}{|c|}{$\Delta Q_{\text {veg }}$} & \multicolumn{2}{|c|}{$\Delta Q_{\text {clim }}$} & \multicolumn{2}{|c|}{$\Delta Q_{\text {veg }}$} & \multicolumn{2}{|l|}{$\Delta Q_{\text {clim }}$} & \multicolumn{2}{|c|}{$\Delta Q_{\text {veg }}$} & \multicolumn{2}{|c|}{$\Delta Q_{\text {clim }}$} \\
\hline & & $\mathrm{mmyr}^{-1}$ & $\%$ & $\mathrm{mmyr}^{-1}$ & $\%$ & $\mathrm{mmyr}^{-1}$ & $\%$ & $\mathrm{mmyr}^{-1}$ & $\%$ & $\mathrm{mmyr}^{-1}$ & $\%$ & $\mathrm{mmyr}^{-1}$ & $\%$ & $\mathrm{mmyr}^{-1}$ & $\%$ \\
\hline Latrobe at Noojee & 1983-1998 & 52 & 17 & 95 & 31 & -44 & -14 & 79 & 26 & -28 & -9 & 66 & 22 & -15 & -5 \\
\hline Yarra River at Little Yarra & 1983-1998 & 36 & 12 & 38 & 12 & -2 & -1 & 20 & 7 & 16 & 5 & 33 & 11 & 3 & 1 \\
\hline Latrobe at Noojee & 1999-2007 & -87 & -29 & 30 & 10 & -117 & -39 & 48 & 16 & -135 & -44 & 4 & 1 & -91 & -30 \\
\hline Starvation Creek & $1999-2004$ & -101 & -24 & 48 & 12 & -149 & -36 & 27 & 7 & -129 & -31 & 21 & 5 & -122 & -29 \\
\hline Yarra River at Little Yarra & $1999-2000$ & -86 & -28 & -25 & -8 & -60 & -20 & 8 & 3 & -94 & -31 & -29 & -10 & -57 & -19 \\
\hline
\end{tabular}

$\Delta Q_{\text {tot }}$ is the difference in observed streamflow between post- and pre- bushfire periods (Eq. 2)

$\Delta Q_{\text {clim }}$ is the impact of climate variability on streamflow, calculated from the difference in simulated streamflow between the post- and pre- bushfire periods (Eq. 3)

$\Delta Q_{\text {veg }}$ is the impact of vegetation change (bushfire) on streamflow, calculated from the difference between $\Delta Q_{\text {tot }}$ and $\Delta Q_{\text {clim }}$.

\section{HESSD}

10, 4397-4437, 2013

Impact of bushfire and climate

variability on

streamflow

Y. Zhou et al.

\section{Title Page}

\section{Abstract}

Conclusions

Tables

14

Back
Introduction

References

Figures

।

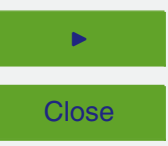

Full Screen / Esc

Printer-friendly Version

Interactive Discussion 
HESSD

10, 4397-4437, 2013

Impact of bushfire and climate

variability on

streamflow

Y. Zhou et al.

Table 6. Calibration and validation results for the GR4J model in four undisturbed catchments.

\begin{tabular}{|c|c|c|c|c|c|c|c|c|c|c|c|c|}
\hline \multirow[t]{2}{*}{$\begin{array}{l}\text { Catchment } \\
\text { code }\end{array}$} & \multirow[t]{2}{*}{$\begin{array}{l}\text { Area } \\
\left(\mathrm{km}^{2}\right)\end{array}$} & \multirow{2}{*}{$\begin{array}{l}\text { Calibration } \\
\text { NSE } \\
(1975-1982)\end{array}$} & \multicolumn{3}{|c|}{ Validation NSE } & \multirow[t]{2}{*}{$\begin{array}{l}\text { Calibration } \\
B\end{array}$} & \multicolumn{3}{|c|}{ Validation $B$} & \multicolumn{3}{|c|}{$\begin{array}{l}\text { B Difference } \\
\text { (validation - calibration) }\end{array}$} \\
\hline & & & $\begin{array}{l}1983- \\
2009\end{array}$ & $\begin{array}{l}1983- \\
1998\end{array}$ & $\begin{array}{l}1999- \\
2009\end{array}$ & & $\begin{array}{l}1983- \\
2009\end{array}$ & $\begin{array}{l}1983- \\
1998\end{array}$ & $\begin{array}{l}1999- \\
2009\end{array}$ & $\begin{array}{l}1983- \\
2009\end{array}$ & $\begin{array}{l}1983- \\
1998\end{array}$ & $\begin{array}{l}1999- \\
2009\end{array}$ \\
\hline 405205 & 109 & 0.58 & 0.73 & 0.72 & 0.58 & 0.13 & 0.07 & 0.07 & 0.06 & -0.06 & -0.06 & -0.07 \\
\hline 405227 & 632 & 0.83 & 0.84 & 0.85 & 0.77 & 0.07 & 0.11 & 0.08 & 0.16 & 0.04 & 0.01 & 0.09 \\
\hline 405209 & 633 & 0.82 & 0.85 & 0.85 & 0.82 & 0.09 & 0.12 & 0.08 & 0.20 & 0.03 & -0.01 & 0.11 \\
\hline 227202 & 1080 & 0.85 & 0.78 & 0.76 & 0.83 & -0.01 & -0.08 & -0.07 & -0.10 & -0.07 & -0.06 & -0.09 \\
\hline
\end{tabular}

Title Page

Abstract

Introduction

Conclusions

References

Tables

Figures

14

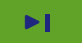

4

Back

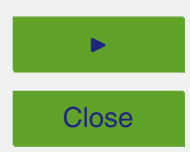

Full Screen / Esc

Printer-friendly Version

Interactive Discussion 

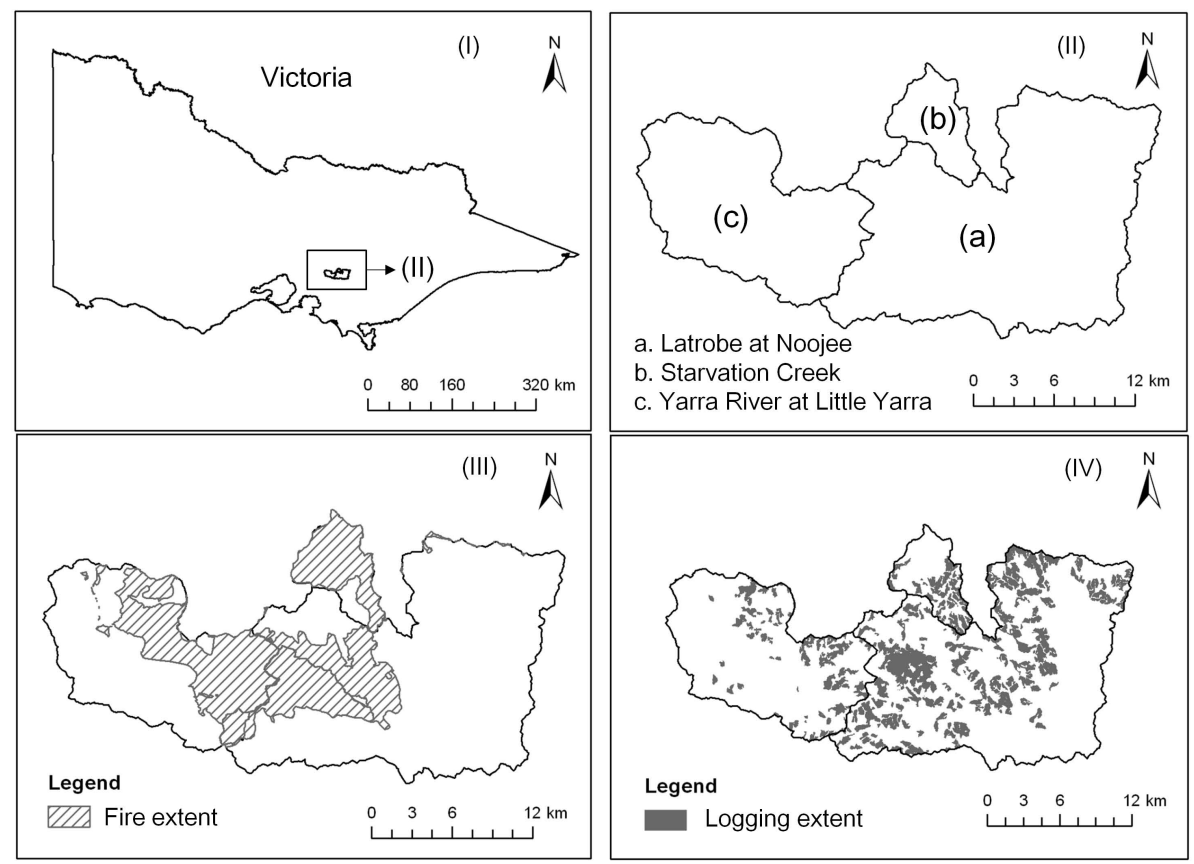

\section{HESSD}

10, 4397-4437, 2013

Impact of bushfire and climate

variability on streamflow

Y. Zhou et al.

\section{Title Page}

\section{Full Screen / Esc}

Printer-friendly Version

Interactive Discussion 

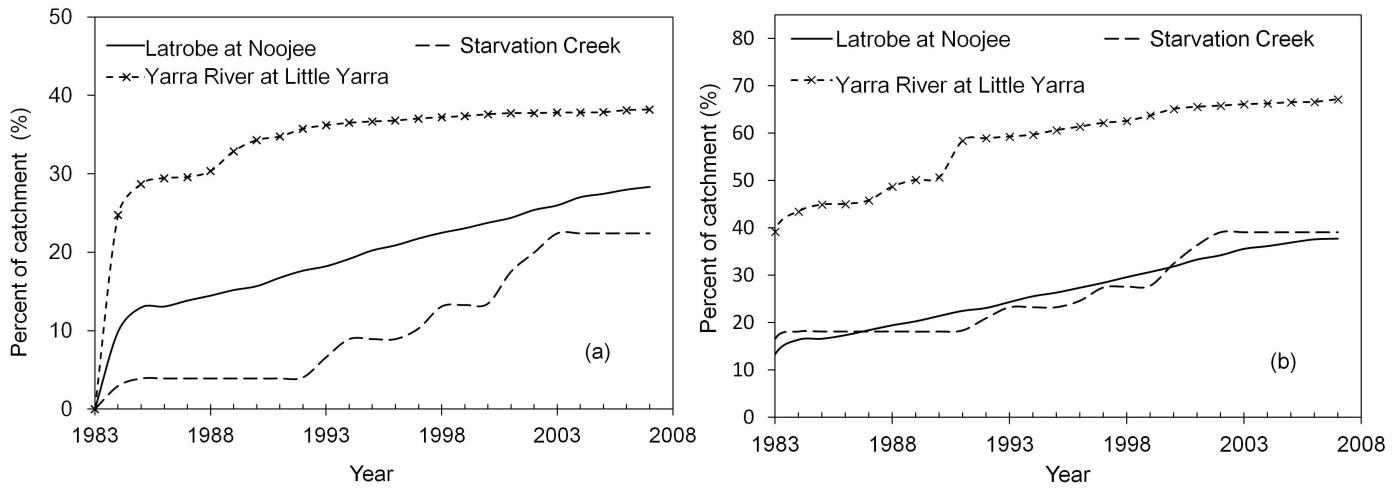

Fig. 2. Cumulative percent of mortality/regrowth for three catchments: (a) mortality/regrowth for ash; (b) mortality/regrowth for all species

HESSD

10, 4397-4437, 2013

Impact of bushfire and climate

variability on

streamflow

Y. Zhou et al.

Title Page

Abstract

Introduction

Conclusions

References

Tables

Figures

14

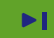

Back

Close

Full Screen / Esc

Printer-friendly Version

Interactive Discussion 


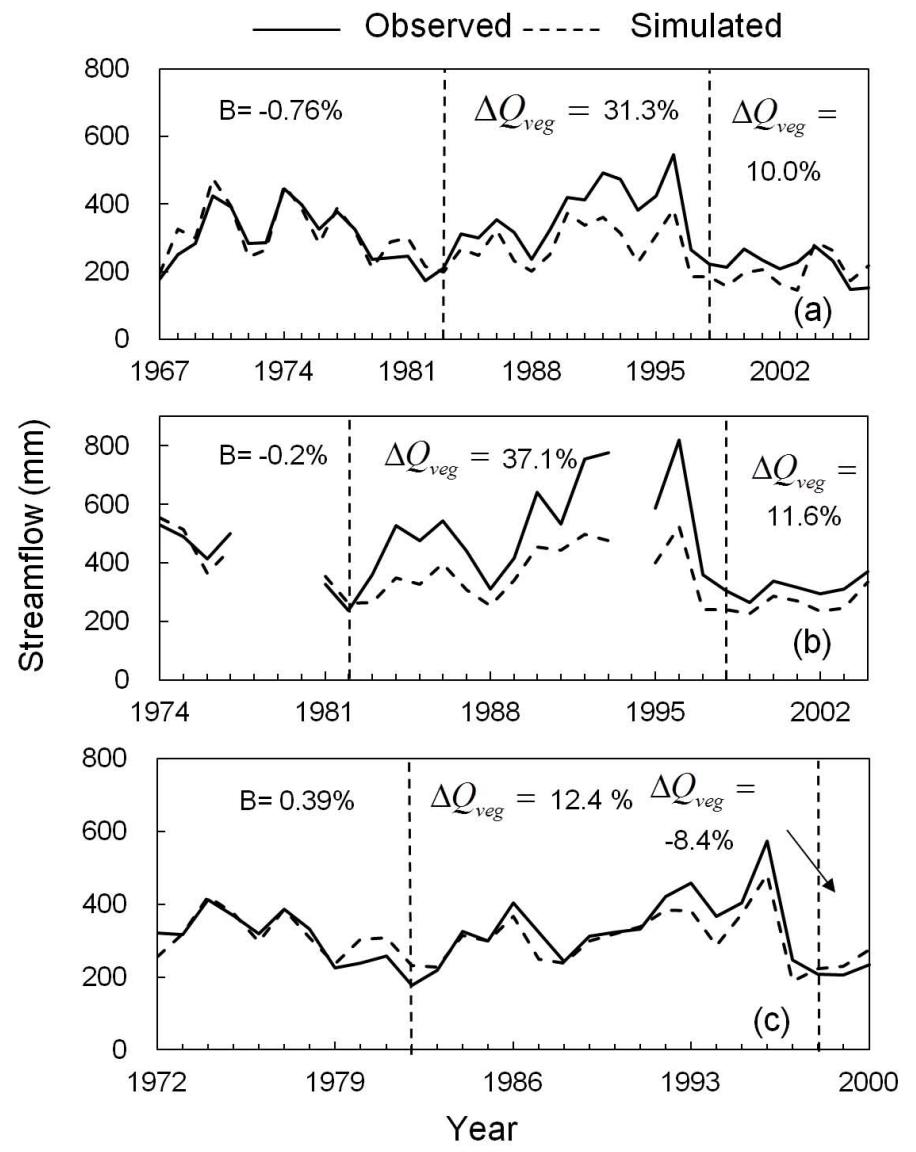

HESSD

10, 4397-4437, 2013

Impact of bushfire and climate

variability on

streamflow

Y. Zhou et al.

Title Page

Abstract

Introduction

Conclusions References

Tables

Figures

14

$\rightarrow$

$\triangleleft$

Back

Close

Full Screen / Esc

Printer-friendly Version

Fig. 3. Variation of observed and simulated annual streamflow at the three catchments for AWRA-L model: Latrobe at Noojee (a), Starvation Creek (b), Yarra River at Little Yarra (c). Two dash lines are for years of 1982 and 1998, respectively

Interactive Discussion 


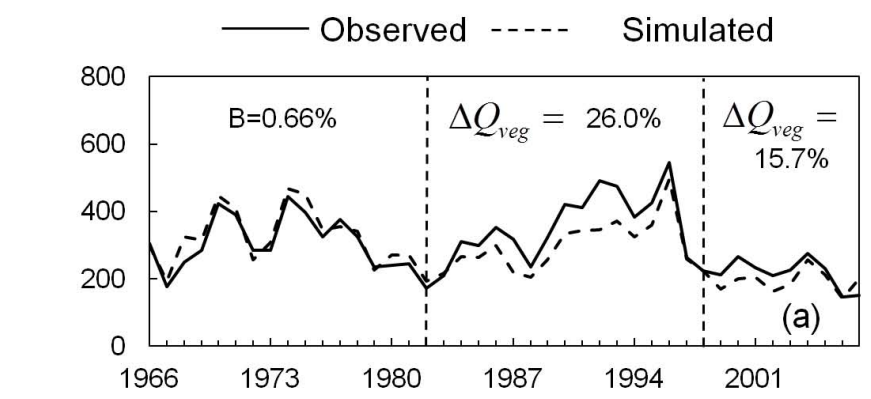

HESSD

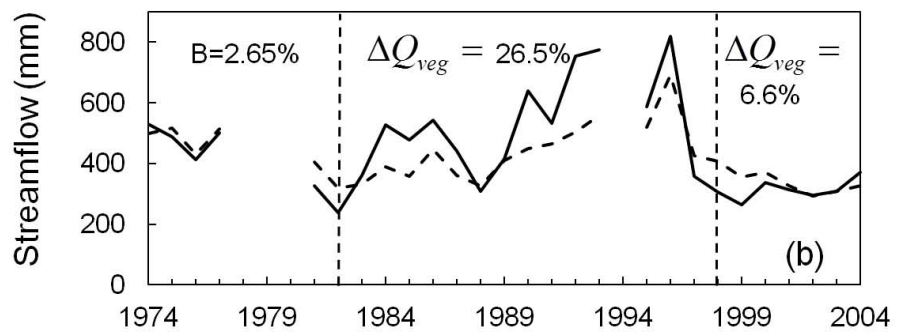

10, 4397-4437, 2013

Impact of bushfire and climate

variability on

streamflow

Y. Zhou et al.

Title Page

Abstract

Introduction

Conclusions

References

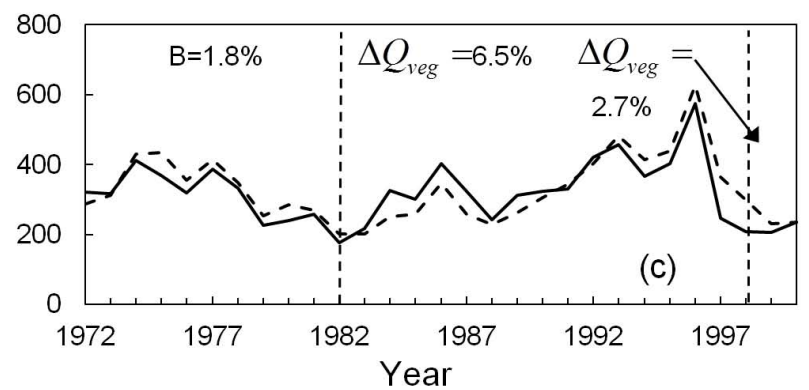

Tables

Figures

14

4

Back

Close

Full Screen / Esc

Printer-friendly Version

Fig. 4. Variation of observed and simulated annual streamflow at the three catchments for XAJ model: Latrobe at Noojee (a), Starvation Creek (b), Yarra River at Little Yarra (c). Two dash lines are for year of 1982 and 1998, respectively 


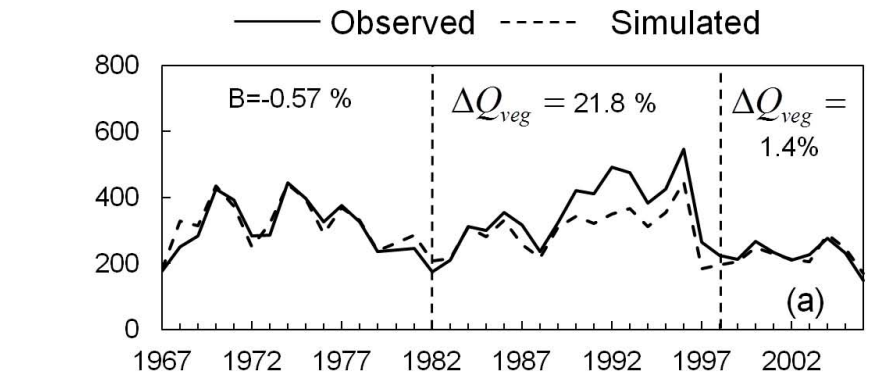

\section{HESSD}

10, 4397-4437, 2013

Impact of bushfire and climate

variability on

streamflow

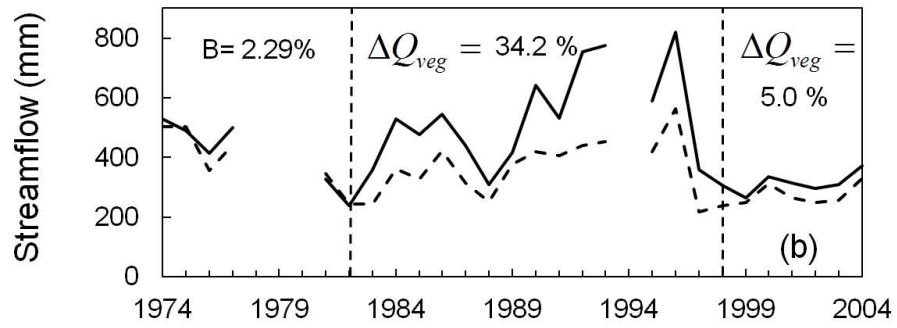

Y. Zhou et al.

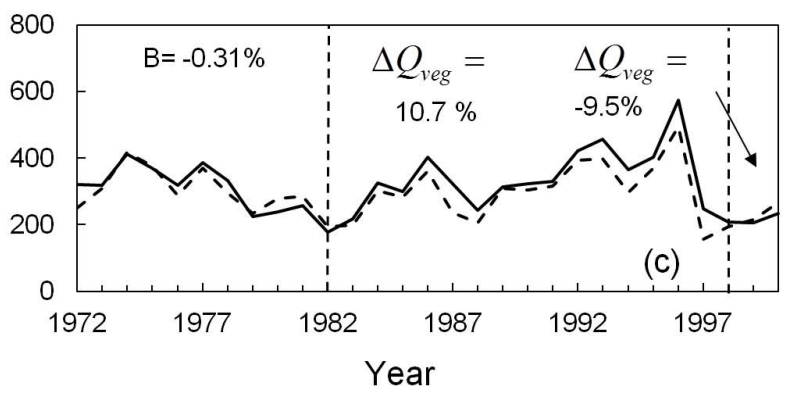

Title Page

4

\section{Full Screen / Esc}

Fig. 5. Variation of observed and simulated annual streamflow at the three catchments for GR4J model Latrobe at Noojee (a), Starvation Creek (b), Yarra River at Little Yarra (c). Two dash lines are for years of 1982 and 1998, respectively 


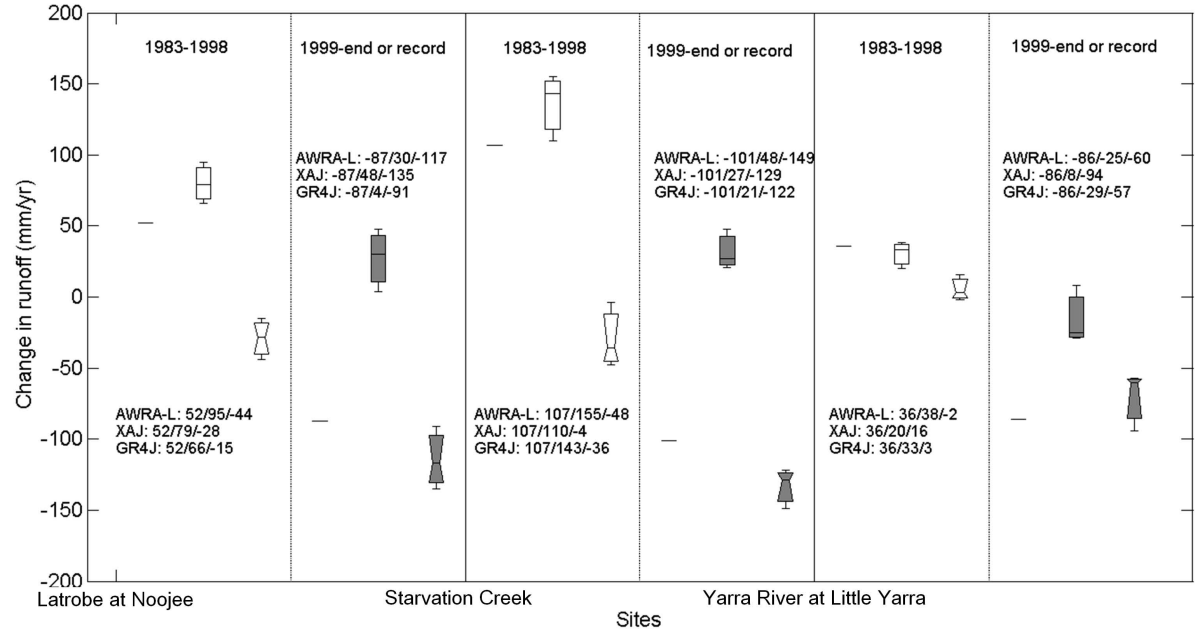

Fig. 6. Summary of bushfire impact on annual streamflow in $\mathrm{mm}$ from the year 1983 to the end year of streamflow record for the three catchments. White boxplots are bushfire impact from the year 1983 to 1998, and gray ones are from the year 1999 to the end year of record. For each catchment, the three white/gray boxplots represent total streamflow change in $\mathrm{mm}$ relative to pre-bushfire period (horizontal line), vegetation change impact on streamflow in $\mathrm{mm}$ (without notch), climate change impact on streamflow in $\mathrm{mm}$ (with notch), respectively.
Impact of bushfire and climate

variability on

streamflow

Y. Zhou et al.

\section{Title Page}

\section{Abstract}

Conclusions

Tables

14

Back
Introduction

References

Figures

$\rightarrow$

$\triangleright$

Close

\section{Full Screen / Esc}

Printer-friendly Version

Interactive Discussion 


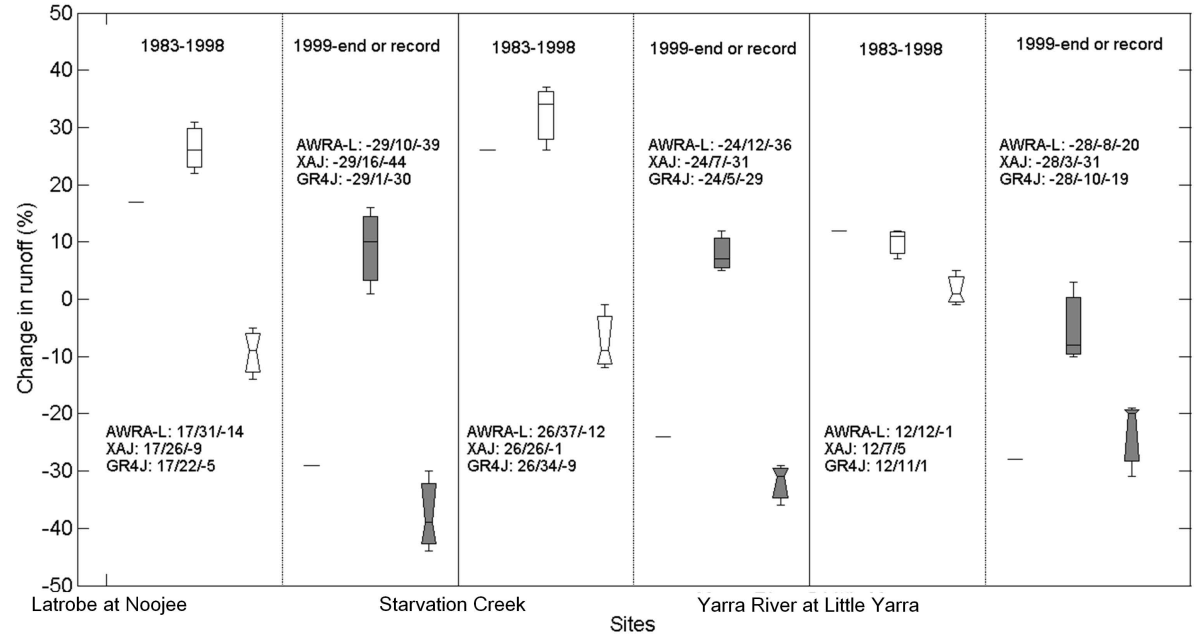

Fig. 7. Summary of bushfire impact on annual streamflow from the year 1983 to the end year of record in percentage for the three catchments. White boxplots are bushfire impact from the year 1983 to 1998, and gray ones are from the year 1999 to the end year of record. For each catchment, the three white/gray boxplots represent total streamflow change relative to pre-bushfire period in percentage (horizontal line), vegetation change impact on streamflow in percentage (without notch), and climate change impact on streamflow in percentage (with notch), respectively
Impact of bushfire and climate

variability on

streamflow

Y. Zhou et al.

\section{Title Page}

\section{Abstract}

Conclusions

Tables

14

Back
Introduction

References

Figures

$\rightarrow 1$

$\triangleright$

Close

\section{Full Screen / Esc}

Printer-friendly Version

Interactive Discussion 